شبيهسازى مكانى - زمانى بارش سالانه با استفاده از مدلهاى تصادفى

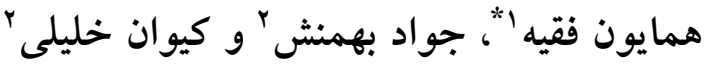

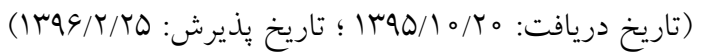

جكيده

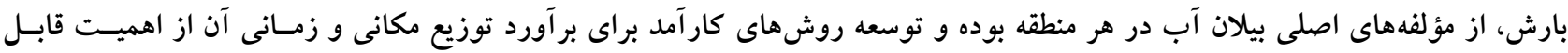

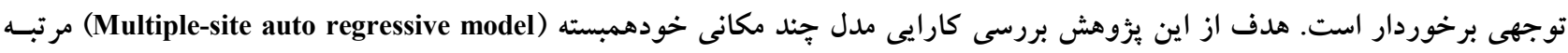

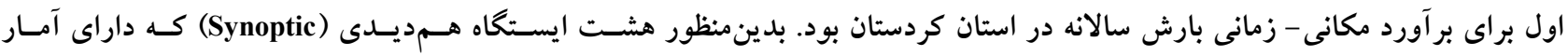

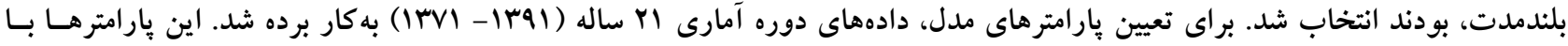

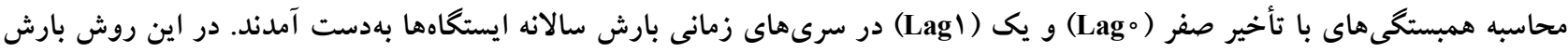

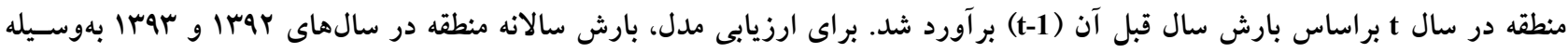

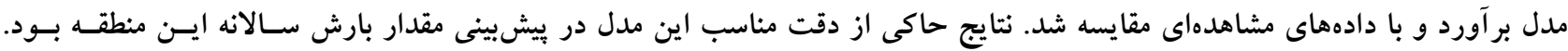

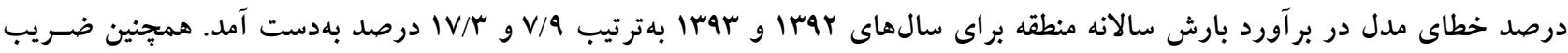

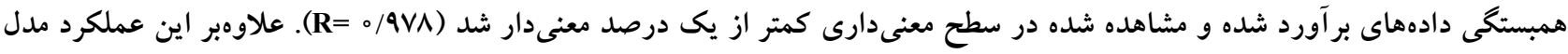

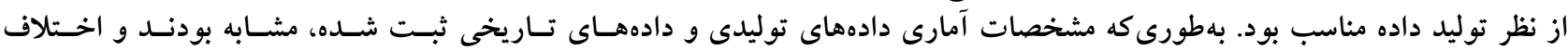

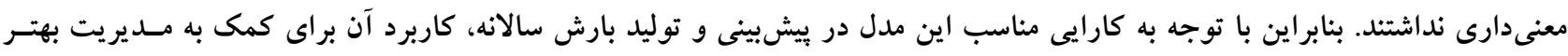
منابع آب اين منطقه قابل توصيه است.

وازههاى كليدى: ييشبينى، خودهمبسته، سرى زمانى، شبيهسازى، كردستان، مدل تصادفى

ا. بخش تحقيقات خاك و آب، مركز تحقيقات و آموزش كشاورزى و منابع طبيعى كردستان، سازمان تحقيقات، آموزش و ترويج كشاورزى r. كروه مهندسى آب، دانشكده كشاورزى، دانشخاه اروميه

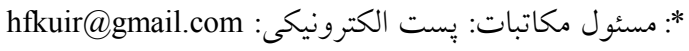


نمود (Yo) (ro)

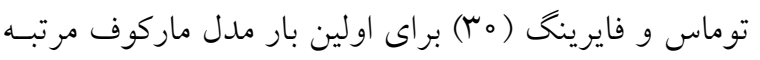
اول با تبديل ويلسون- هيلفرتى را براى توليد دادههـاى جريـان

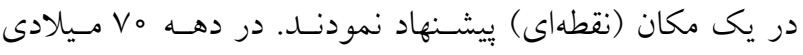
باكس و جنكينس (r) اين مدلها را توسعه دادنــ. آنها شسيوه تجزيه و تحليل سرىهاى زمانى را توصيف نمودند. سـريكانثان و مكماهون (Y) مدل ماركوف مرتبه اول با تبــيل ويلسـونهيلفرتى را براى توليد دادههاى بــارش سـالانه توصسيه نمودنــــ.

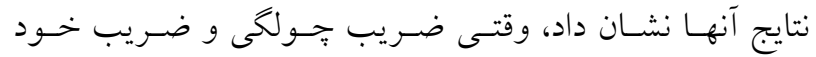
همبستخى با تأخير يكى دادهها نزديكى صفر است، اين مــدل بـهـ

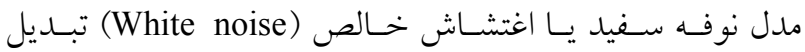

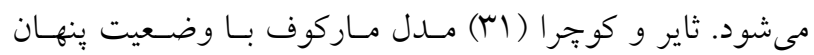
(Hidden State Markov (HSM)) براى توليد دادههاى بارش سالانه سيدنى استراليا توسـعه دادنـــ.

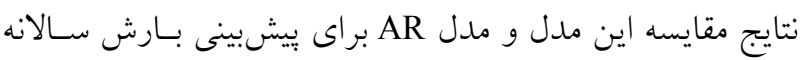

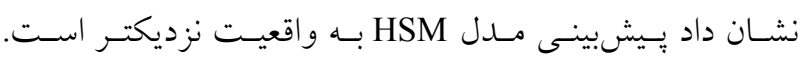

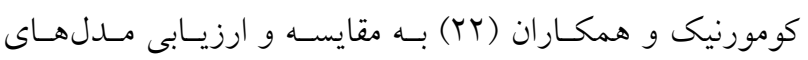

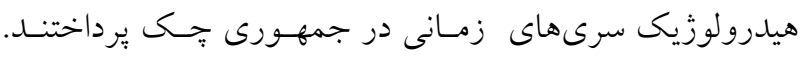

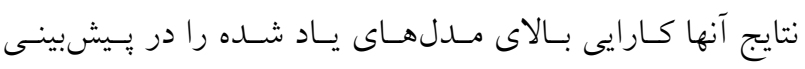
فرآيندهاى هيدرولوزيكى نشان مى دهد. خليلى و همكاران (YI)

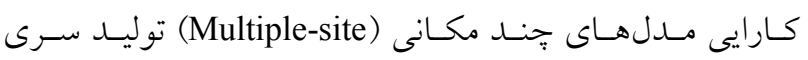

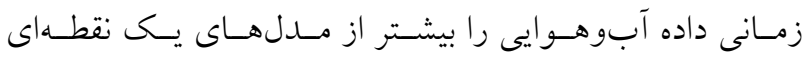
ارزيابى نمودهاند. سعدا (Single site)

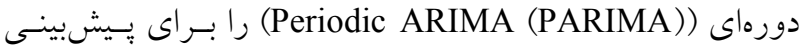
بارش ماهانه در مناطق خشك و نيمـهخشـك مناسـب دانسـت.

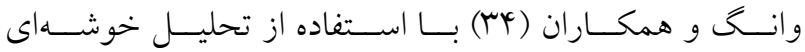
دقت مدل آريما را در ييشبينى بـارش (Clustering analysis) ماهانه ايستگاه لانزو در جين (الr درصد) افزايش دادند.

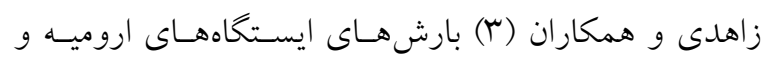

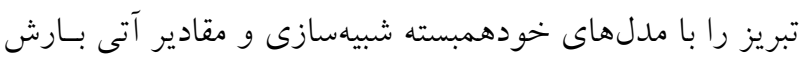

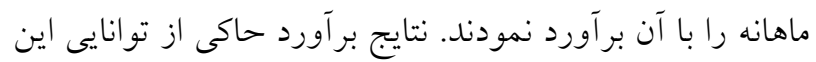

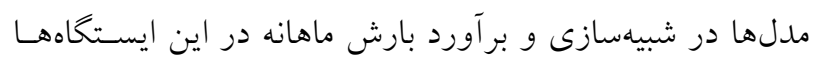

كميتهاى قابل اندازهگيرى بديدههـاى مختلـف خرخـه آب را

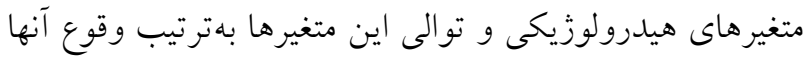
در زمان، را سرىهاى زمانى مىنامند. توصيف رفتسار بديـــه در

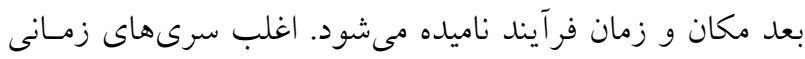
متغيرهاى هيدرولوزيكى از يكى فرآينــ غيـــ قطعى (تصـادفى)

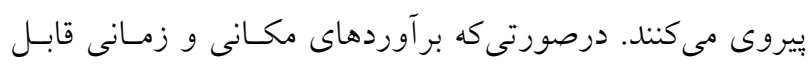

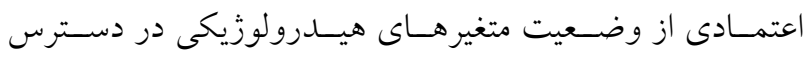

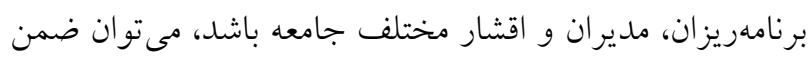

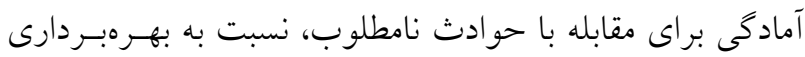

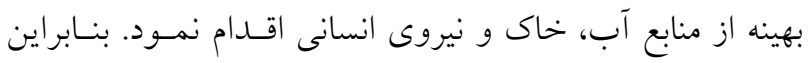
يــيشبينسى و تحليـل سـرىهـاى زمـانى، اسـاس بسـيارى از

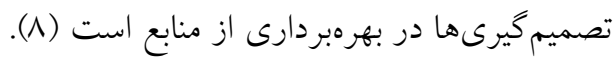

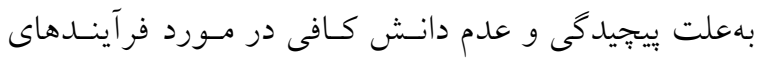

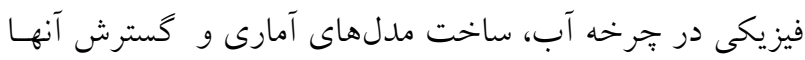

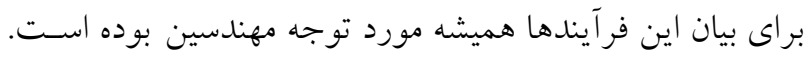

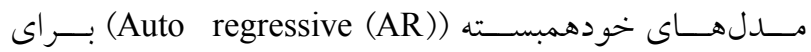
شبيهسازى سالانه و يا فصلى سرىهاى زمانى بهكـار مسرونـــ.

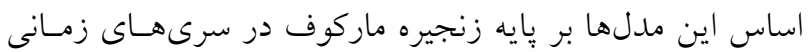

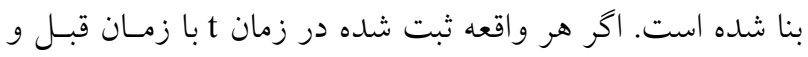

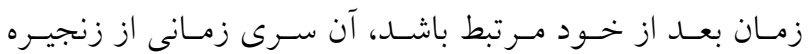

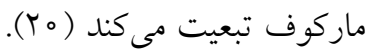
مدلهاى خودهمبسته بهدليل سادكى، استفاده گسـتردهاى در

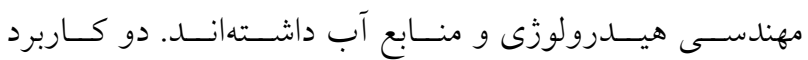

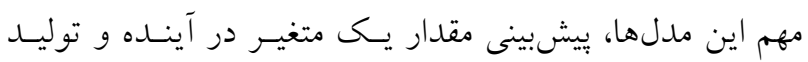

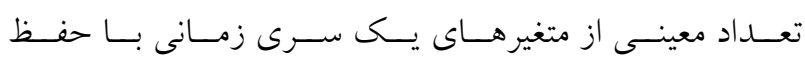

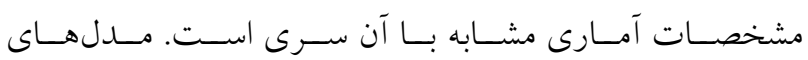

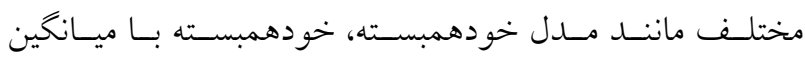
متحسرى (Auto regressive moving average (ARMA))

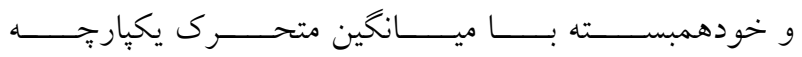
(Auto regressive integrated moving average (ARIMA)) را مىتوان بهعنوان انتخابهاى ممكن براى شبيهسـازى اسـتفاده 
مىشود (1). شكل (1) موقعيت استان كردستان در غـرب ايـران را نشان مىدهد. استان كردستان بهدليل داشتن ارتفاعات متعدد و بارشهــاى

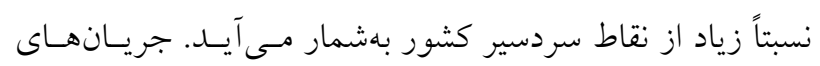

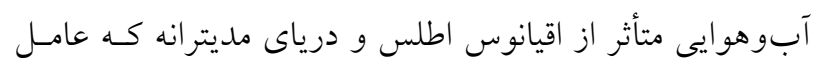

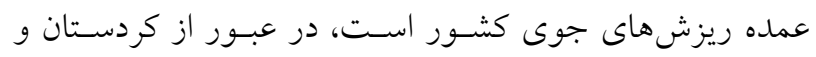

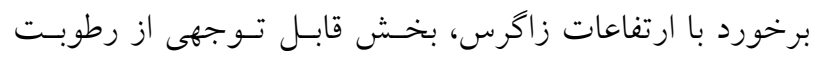

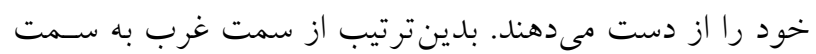

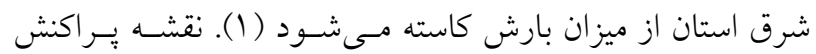

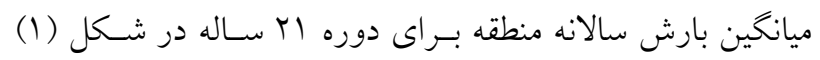

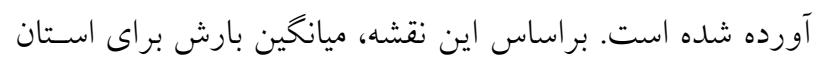

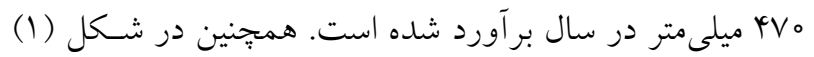
نقشه مدل رقومى ارتفاع استان كردستان ارائه شده است. در اين يُزوهش براى رسم نقشهها از نرم|فزار ArcMap10 استفاده شد.

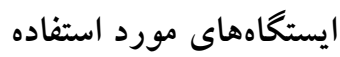

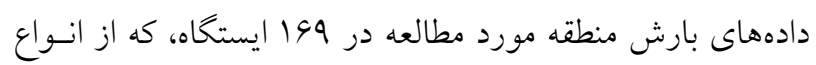

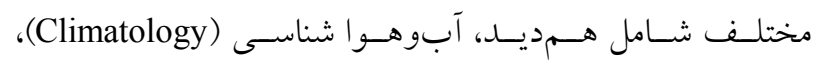
بارانسنجى و تبخير سنجى بودند، ثبت شده است. برخى از ايسن إنس

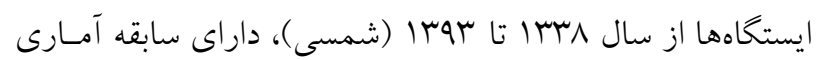

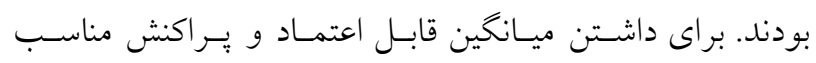

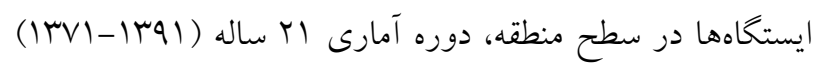

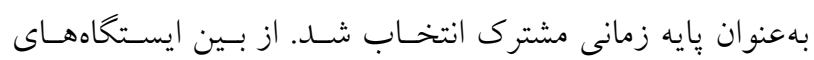

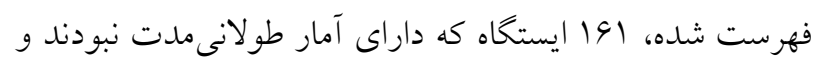

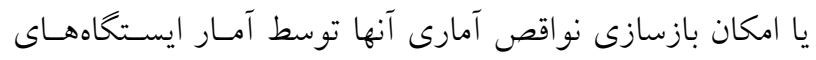
مجاور وجود نداشت، حذف شدند. بدين ترتيب هشت ايستشاه بـاه همديدى، كه داراى يراكنش مناسبى در سطح منطقه بودند، براى نهاى

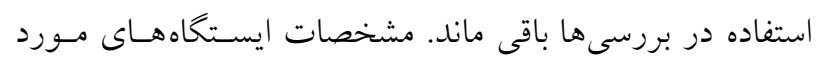
استفاده در جدول (1) ارائه شده است.

\section{آمادهسازى دادهها}

بيش از تجزيه و تحليل آمارى لازم است كميت، كيفيت و كامل
بود. شريفان و قهرمان (Y) از شـبيهسـازى بـارش ماهانـه بـــاى كاى

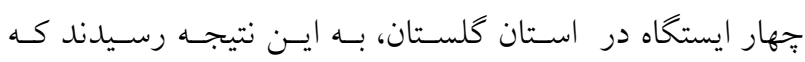

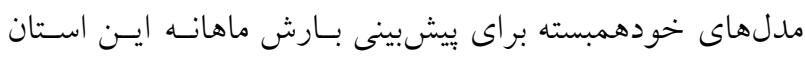

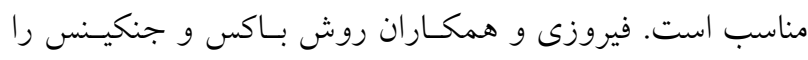

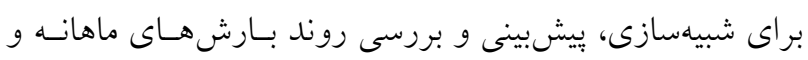

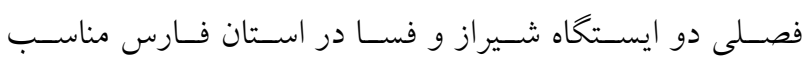

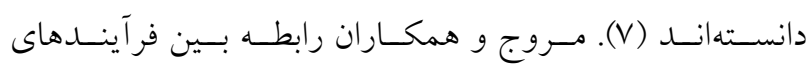

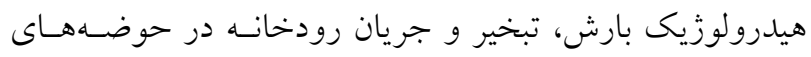

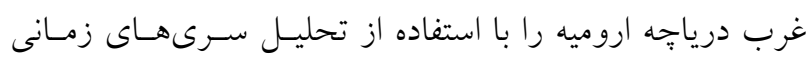

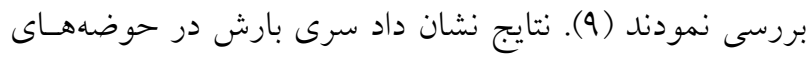

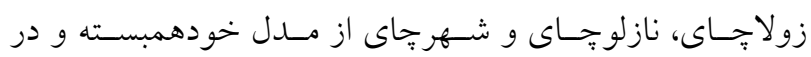

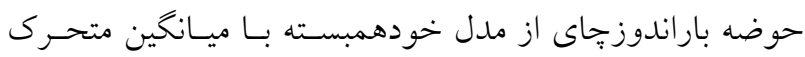
تبعيت مى كند.

هدف از اين يُزوهش ارزيابى مدل جند مكـانى (منطقـهاى)

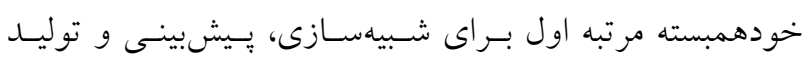

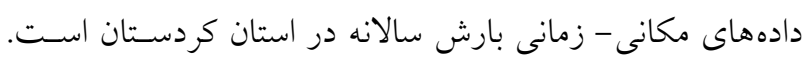

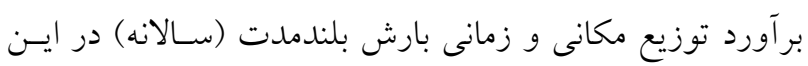

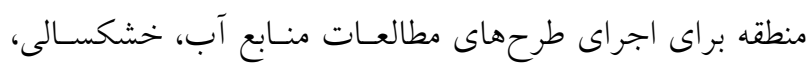

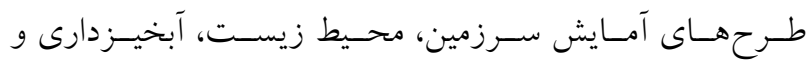

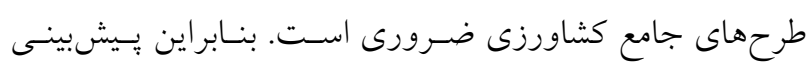

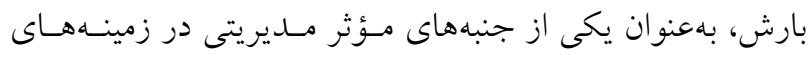

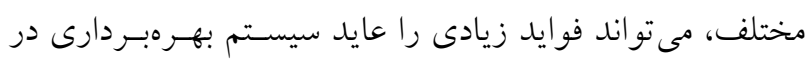
منطقه كند.

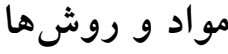

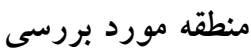

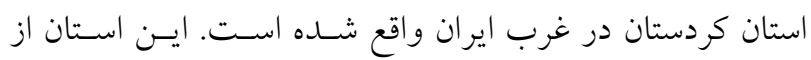

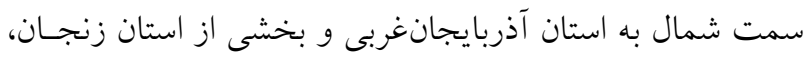
از جنوب به استان كرمانشاه، از شرق به استان همدان و قسـمت ديخرى از استان زنجان و از طرف غرب به به كشور عراق محدود

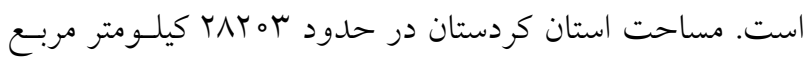
بوده كه اين مساحت الدا درصد از وسعت كل كشور را شامل 


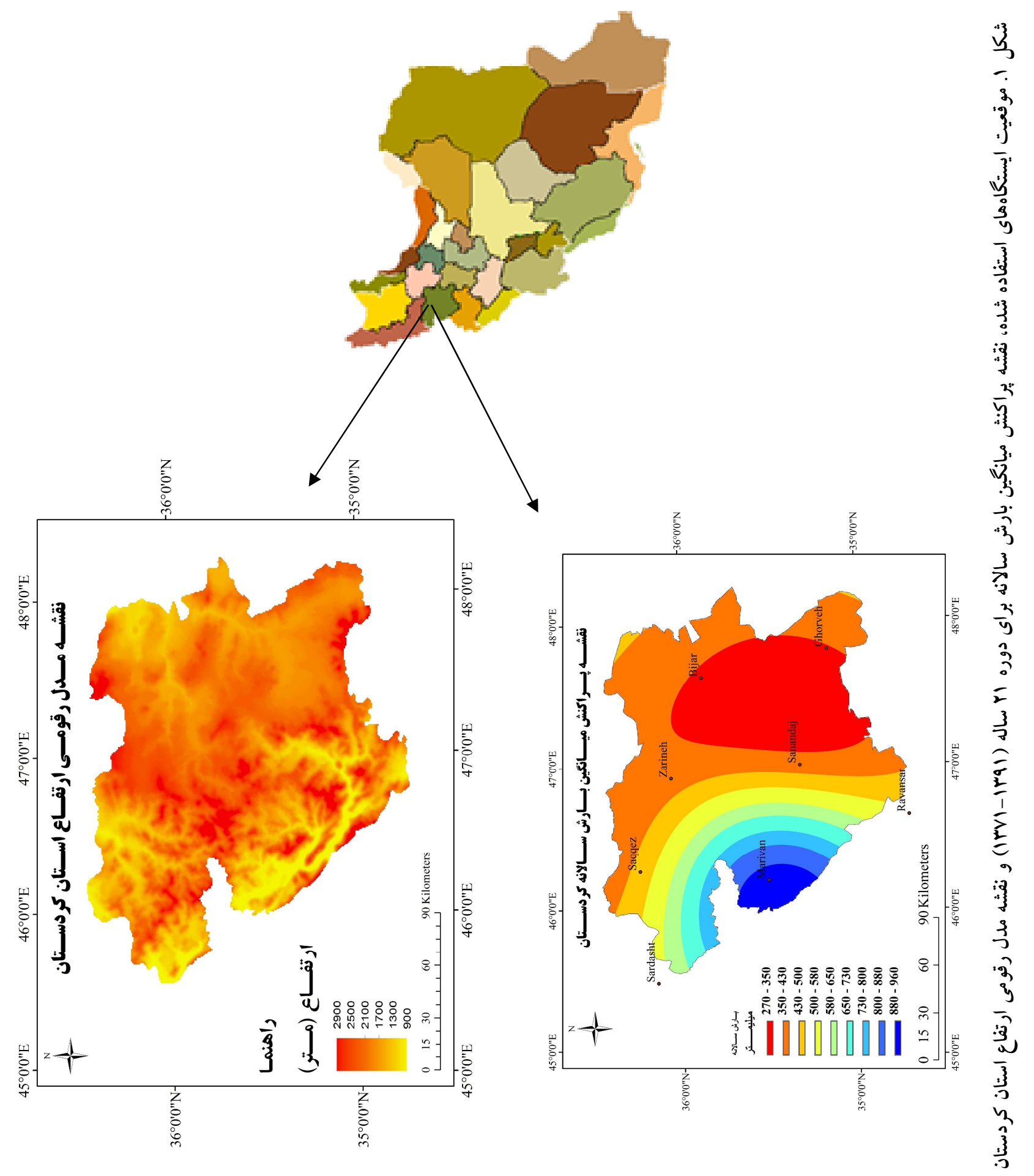


جدول ا. مشخصات ايستخاههاى همديد استفاده شده در اين يُوهش

ايستخاه (شماره)

\begin{tabular}{|c|c|c|c|c|c|c|c|c|}
\hline زرينه (N) & سردشت (V) & سقز (4) & سنندج (ه) & روانسر (4) & مريوان (r) & قروه (Y) & بيجار (1) & \\
\hline rikr & $100 \mathrm{~V}$ & IOTH & IrVT & $\mid r \Lambda 。$ & ITAV & 1909 & lMAr & ارتفاع از سطح دريا (m) \\
\hline $4 \varphi^{\circ} \Delta \Delta^{\prime}$ & $Y Q^{\circ} Y q^{\prime}$ & $49^{\circ} 19^{\prime}$ & $Y V^{\circ} \circ \circ^{\prime}$ & $4 \varphi^{\circ} r q^{\prime}$ & $49^{\circ} \mid r^{\prime}$ & $r V^{\circ} Y \Lambda^{\prime}$ & $r V^{\circ} r V^{\prime}$ & طول جغرافيايى \\
\hline rqo of' & rqo ०q' & re् $10^{\prime}$ & $r \Delta^{\circ} Y_{\circ}$ & proprl & ro० rا' & $r \Delta^{\circ} 10^{\prime}$ & $r \Delta^{\circ} \Delta r^{\prime \prime}$ & عرض جغرافيايى \\
\hline TQ & rq & $\Delta t$ & 09 & rV & r & rq & r^ & دوره آمارى (سال) \\
\hline $\mathrm{rab}$ & AVG & YQV & mar & DIr & $9 r_{0}$ & mey & 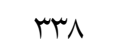 & ميانگين بارش سالانه (mm) \\
\hline
\end{tabular}

و بهوسيله آنها به توزيع نرمـال انتقـال داده مسىشـدند. انتخـاب توزيـع احتمـال مناسـب بـا اسـتفاده از روشهــاى (منطقـهاى) كشتاورهاى خطى (IV) (Linear Moments (L-Moments) و يـك مكسـانى (نقطـهاى) نمــودار احتمــال ضـريب همبسـتحى (19) (Probability Plot Correlation Coefficient(PPCC))

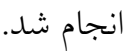

\section{آزمون گرابز}

در اين روش مقدار آماره كرابز (T)، با توجه به تعداد دادههـا و درصد ريسك مجاز براى خطا در حسذف يـى داده، از جـدول

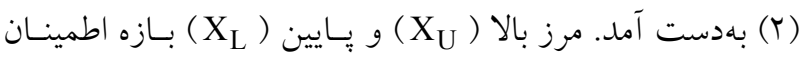
دادهها با استفاده از رابطههاى ا و Y محاسـبه و دادههـا بـا آنهـا مقايسه شدند. دادههاى كو جكتر از مرز پايين و بزرگتــ از مـرز بالا بهعنوان داده برت تعيين شدند. اين دادههـاى يـرت ممكـن

است واقعى باشند اما از نظر آمارى برت بهحساب آمدند (ه). $\mathrm{X}_{\mathrm{U}}=\overline{\mathrm{X}}+\mathrm{T} . \mathrm{S}$

$\mathrm{X}_{\mathrm{L}}=\overline{\mathrm{X}}-\mathrm{T} . \mathrm{S}$ در رابطههاى ا و r X مورد آزمون است.

\section{آزمون توالى}

در اين روش هريك از ارقام سرى با ميانخين دادهها مقايسه شد. دادههاى بزركتر و كو جكتر از ميانكين بهترتيب بـا حـرف a و b مشخص شدند. براى دادههاى برابر با ميانخين علامتسى كذاشته
بودن دادهها بررسى شود. در اين يـزّوهش بازسـازى دادههـا و تطويل آمارها به كمك روش همبسـتخى بـين ايستـاههـا (10) انجام شد. در اين روش بهوسيله رگرسيون خطى آمـار ايستخاه ناقص (بهعنوان متغير وابسته و مجهول) با استفاده از دادههـاى ايستخاه مبنا (بهعنوان متغير مستقل و معلـوم) تخمسين زده شـد.

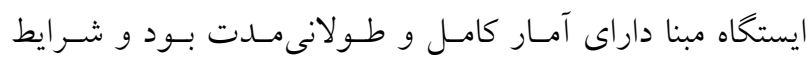
جغرافيايى و آبوهوايى تقريباً يكسانى با ايستخاه ناقص داشت. از آنجا كه در اين بررسى، يكى از معيارهاى انتخاب ايستخاههـا كامل بودن سرى دادههاى آنها بود، بنابراين بازسازى كمى بـراى

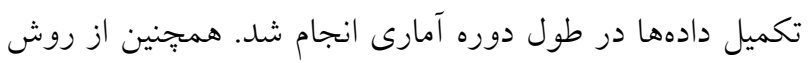

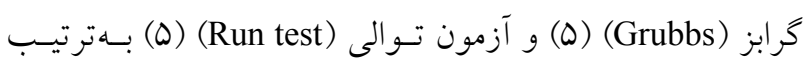
براى تعيين دادههاى پِرت (Outlier) و بررسى همخنى دادههـاى آمارى ايستخاههاى مورد بررسى استفاده شد. براى مدلسـازى آمـارى تشـخيص وجـود و از بـين بـردن ترمهاى (بخشهاى) قطعى قابـل توجـه در سـرى دادههـا لازم

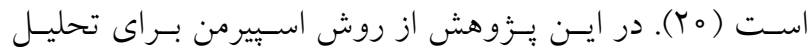
وجود نايستايى در سرىهاى زمانى دادهها استفاده شد (TV). در صورت وجود روند براى حسـف آن در سـرى دادههـا از روش حداقل مربعات استفاده شد (هو ر). نرمال بودن سرى زمانى از فرضـيات بسـيارى از مــلهــاى

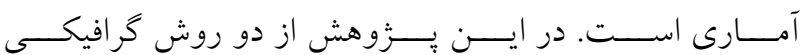

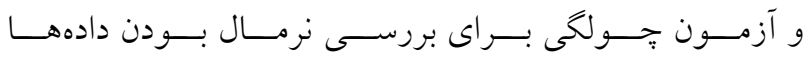

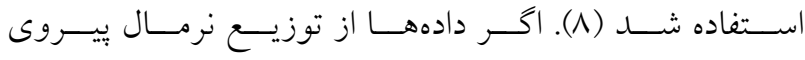
نمسى كردنــد، آنهـا را بــا توزيـع هــاى آمـارى مناسـب بــرازش 
جدول r. مقدار آماره گرابز (T) (ه)

\begin{tabular}{|c|c|c|c|c|c|c|c|c|c|c|c|}
\hline \multicolumn{5}{|c|}{ ريسك اشتباه در حذف داده (درصد) } & \multirow{2}{*}{$\begin{array}{c}\text { تعداد دادهها } \\
\text { (N) }\end{array}$} & \multicolumn{5}{|c|}{ ريسك اشتباه در حذف داده (درصد) } & \multirow{2}{*}{$\begin{array}{c}\text { نعداد دادهها } \\
\text { (N) }\end{array}$} \\
\hline 10 & 0 & 1 & $\circ / 0$ & $\circ / 1$ & & 10 & 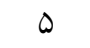 & 1 & $\circ / 0$ & $\circ / 1$ & \\
\hline r/OrG & T/IVG & $Y / 4 \mid \circ$ & T/YAT & $r / 9 \circ 9$ & 10 & $1 / 14 \wedge$ & l/ & $1 / 100$ & $1 / 100$ & $1 / 100$ & r \\
\hline Y/YYV & $r / 4 \circ q$ & $Y / V \circ Q$ & $r / \Lambda \circ 9$ & $r / 99 V$ & 10 & $1 / 4 T D$ & $1 / 4 \& \pi$ & $1 / 494$ & $1 / 494$ & $1 / 499$ & i \\
\hline$r / T \wedge D$ & $r / \Delta Q V$ & Y/AMY & $r / 001$ & 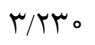 & ro & $1 / 9 \circ Y$ & $1 / 9 V T$ & $1 / v+q$ & I/VGY & I/VA。 & 0 \\
\hline T/YAS & r/99Y & $r / \circ \circ q$ & ه & ґ/ґ & TQ & $1 / V Y q$ & I/ATt & $1 / 944$ & $1 / 9 \sqrt{2}$ & $r / 011$ & 4 \\
\hline T/VGA & $r / 909$ & ( ) & r/ץ r & r/vAq & Q. & I/AYA & $1 / 9 \mu \wedge$ & $Y / \circ 9 V$ & $r / T r q$ & $Y / Y \circ 1$ & V \\
\hline \multirow[t]{2}{*}{$\mathrm{r} / 01 \mathrm{~V}$} & $r / T \circ V$ & r/9०० & $r / V Q \varphi$ & $\varphi / \circ \wedge \uparrow$ & 100 & $1 / 9 \circ 9$ & T/OHT & Y/YYI & $T / T V{ }^{*}$ & $r / r \Delta \Lambda$ & $\wedge$ \\
\hline & & & & & & $1 / 9 \mathrm{VV}$ & $r / l 1 \circ$ & מזץ/ץ & $r / \mu \wedge V$ & $r / 4 q r$ & 9 \\
\hline
\end{tabular}

$\mathrm{Z}_{\mathrm{SR}}=\frac{\mathrm{D}}{\sqrt{\operatorname{Variance}(\mathrm{D})}}$

$[\emptyset]$

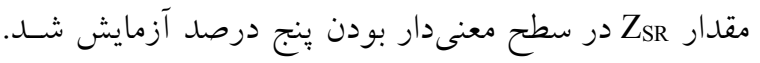

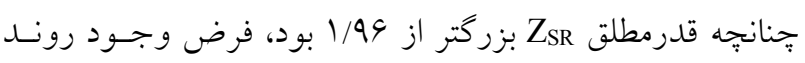
در سرى دادهها بذيرفته شد. در غير اين صـورت سـرى دادههـا تصادفى و بدون روند درنظر خرفته شدند.

آزمون جولخى اخر جولكى يكى سرى زمـانى ( محدوده

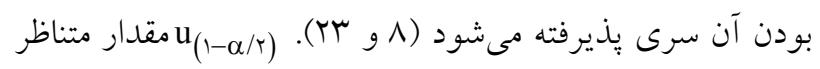

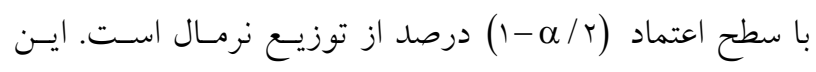

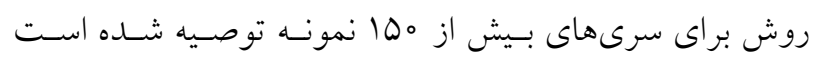

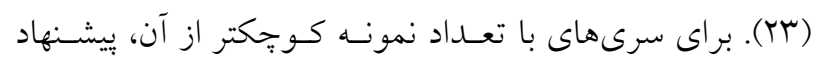

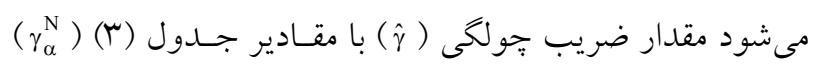

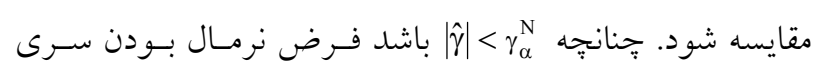

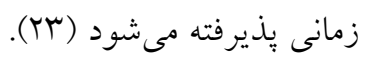

\section{روش گثتاورهاى خطى}

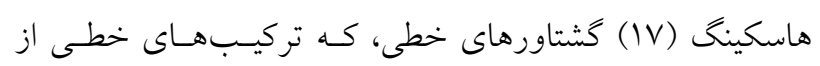

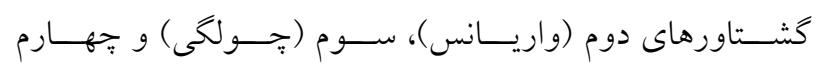

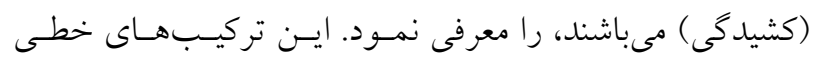

نشد و اين خنسين حسالتى مـانع از ادامـه تـوالى اعـداد نخرديــا.

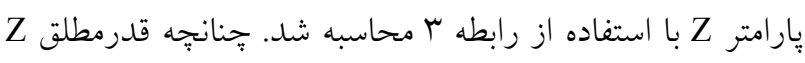

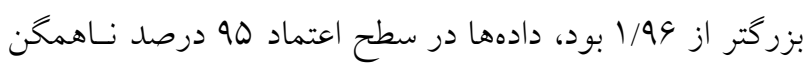

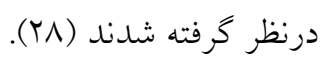

$$
Z=\frac{r-\left[\left(\frac{r m n}{m+n}\right)+1\right]}{\sqrt{\frac{(r m n \cdot(r m n-m-n))}{\left((m+n)^{r} \cdot(m+n-1)\right)}}}
$$

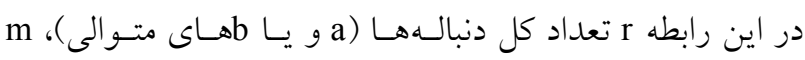

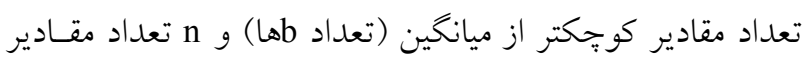

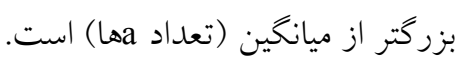

$$
\text { آزمون اسييرمن }
$$

براى انجام اين آزمون دادههـا بـهـ شـكل افزايشـى مرتـب و و بــهـ

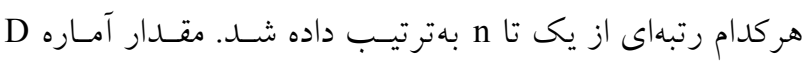

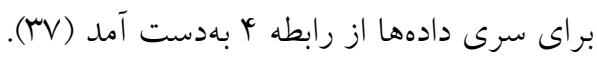

$\mathrm{D}=1-\frac{4 \sum_{\mathrm{i}=1}^{\mathrm{n}}\left[\mathrm{R}\left(\mathrm{x}_{\mathrm{i}}\right)-\mathrm{i}\right]^{\top}}{\mathrm{n}\left(\mathrm{n}^{r}-1\right)}$

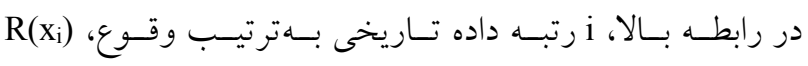

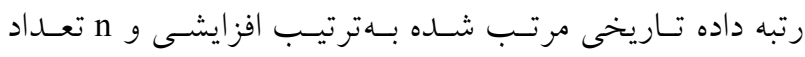

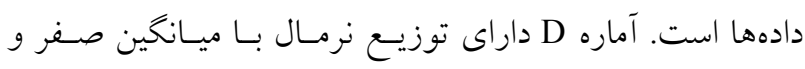
واريانس (

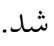


جدول r. مقادير ( $\left.\gamma_{\alpha}^{N}\right)$ براى سنجش نرمال بودن سرىهاى كمتر از •10 نمونه (rr)

\begin{tabular}{|c|c|c|c|c|c|c|c|c|}
\hline$\alpha=\circ / \circ r$ & $\alpha=\circ / \circ 1$ & تعداد نمونه & $\alpha=\circ / \circ r$ & $\alpha=0 / 01$ & تعداد نمونه & $\alpha=\circ / \circ r$ & $\alpha=\circ / \circ 1$ & تعداد نمونه \\
\hline - DQSV & $\circ / \mu \wedge q$ & 100 & $\circ / \mathrm{V} \wedge \mathrm{V}$ & -/OHY & Q & $1 / 091$ & $\circ / 211$ & TQ \\
\hline$\circ / 0 \circ \wedge$ & •/గ山。 & ITO & ONYT & $0 / 4 q r$ & 90 & $0 / 919$ & - 1945 & r。 \\
\hline $0 / 4 q 4$ & O/MYI & $10 \circ$ & $0 / 9 \mathrm{VT}$ & $\circ / 4 \Delta Q$ & V。 & ס/9rT & O/GYI & ro \\
\hline \multirow[t]{2}{*}{$\circ / 4 T_{0}$} & $0 / r q \wedge$ & IVD & O/SMI & o/frt & $\Lambda \circ$ & $\circ / \Lambda V^{\prime}$ & $\circ / \Delta \wedge \vee$ & ro \\
\hline & & &.$/ 099$ & $\circ / 4 \circ q$ & 90 & - /ATQ & - /QQA & id \\
\hline
\end{tabular}

يار امترى از گشتاورهاى خطى جــولخى ( ) استفاده شد. مقدار تئسورى كشـتاورهاى خطى توزيـعهـاى دو

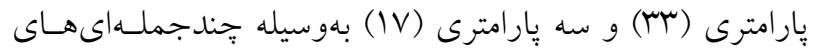

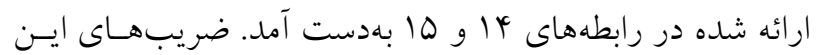
جندجملهاىها در جدول (Y) ارائه شده است. $\tau_{r}=\mathrm{A}_{o}+\mathrm{A}_{1} \tau_{r}^{\prime}+\mathrm{A}_{r} \tau_{r}^{r}+\ldots+\mathrm{A}_{V} \tau_{r}^{\vee}$ $\tau_{\varphi}=\mathrm{A}_{\circ}+\mathrm{A}_{1} \tau_{\mu}^{\prime}+\mathrm{A}_{r} \tau_{\mu}^{r}+\ldots+\mathrm{A}_{\wedge} \tau_{r}^{\wedge}$

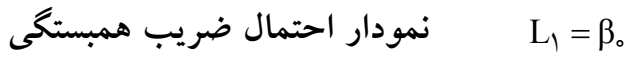

فيليبن اين روش ساده و كارآمد را براى انتخاب توزيع احتمـال مناسب در يك مكان (ايستخاه) بسط داد (9)). در ايسن روش

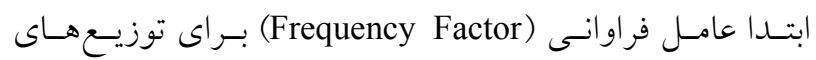
احتمال برآورد شد. سبِ با استفاده از رابطه جِاو مقادير متنـاظر و هم احتمال وقوع با دادههاى مشاهدهايى بر آورد شـد. ضـريب همبستخى دادههاى مشاهدهايى و عامل فراوانى توزيعها محاسبه و با يكديخر مقايسه شد. توزيعى كه داراى بـالاترين همبسـتى لئى بود، بهعنوان توزيع مناسب انتخاب شد. همجنين در ايـن روش

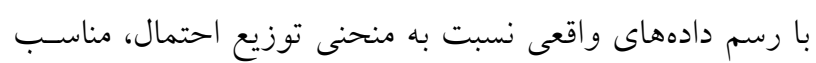
بودن آن توزيع براى برازش دادهها كنترل شد (YY).

\section{روش عامل فراوانى} جاو رابطه 19 را بــراى بــرازش دادههــا بـا توزيـعهـاى تئسورى احتمال بيشنهاد نمود (10).
$\mathrm{L}_{\Upsilon}=\Upsilon \beta_{1}-\beta_{\circ}$

كشتاورها براى نمونههـاى كو جـك ناريـب بـوده و نسـبت بـهـ دادههاى يرت حساس نيستند. بنابراين كاربرد آنهـا بـراى تعيسين

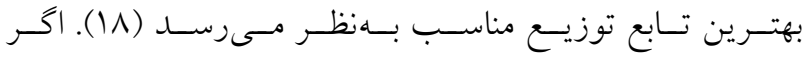
دادهاى يك نمونه تصادفى باشند و ايسن سـرى Xl, XY,., Xn بهلهـور افزايشـى مرتسب شـود، سـرى X خواهد شد. كشتاورهاى خطى و نسـبتهـاى آنهـا مربـوط بــه

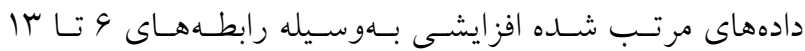
محاسبه شدند.

$\mathrm{L}_{\mu}=q \beta_{r}-9 \beta_{1}-\beta_{\text {。 }}$

$L_{r}=r \circ \beta_{r}-r \circ \beta_{r}+\mid r \beta_{1}-\beta_{\circ}$

$\beta_{r}=n^{-1} \sum_{j=r+1}^{n}\left(\begin{array}{c}j-1 \\ r\end{array}\right)\left(\begin{array}{c}n-1 \\ r\end{array}\right)^{-1} X_{(j, n)}, r=\circ, \ldots, n-1[10]$

$\tau_{\Upsilon}=\mathrm{L}-\mathrm{CV}=\frac{\mathrm{L}_{\Upsilon}}{\mathrm{L}_{1}}$

$\tau_{\mu}=\mathrm{L}-$ Skewness $=\frac{\mathrm{L}_{\Gamma}}{\mathrm{L}_{\Gamma}}$

$\tau_{\uparrow}=\mathrm{L}-$ Kurtosis $=\frac{\mathrm{L}_{\uparrow}}{\mathrm{L}_{\Upsilon}}$

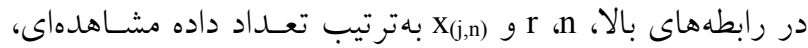
مرتبه كُتاور و داده مشاهدهاى مرتب شده (بهصورت افزايشى)

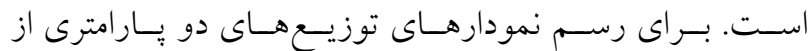

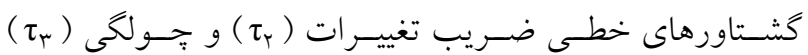

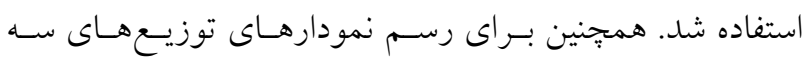


جدول f. ضريبهاى جِندجملهاىهاى تخمين گثتاورهاى خطى براى توزيعهاى آمارى مختلف

\begin{tabular}{|c|c|c|c|c|c|c|c|c|}
\hline $\begin{array}{l}\text { نمايى } \\
\text { (E) }\end{array}$ & $\begin{array}{c}\text { يكنواخت } \\
\text { (U) }\end{array}$ & كامبل & $\begin{array}{l}\text { نرمال } \\
\text { (N) }\end{array}$ & $\begin{array}{c}\text { كام } \\
\text { (Gamma) }\end{array}$ & لو لو يَ نرمال & 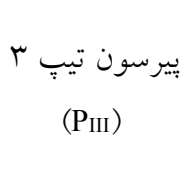 & لو سه نومال & ضريب \\
\hline- & - & - & - & $\circ$ & $\circ$ & ONMTYO & O/ MYAY & A。 \\
\hline- & - & - & - & INATIM & $1 / 19 \circ 01$ & 。 & $\circ$ & $A_{1}$ \\
\hline- & - & - & - & $\circ$ & $-0 / 0 \Delta Y Y Q$ & $\circ / N \circ \| 0$ & $\circ / V \vee D \backslash \wedge$ & $A_{r}$ \\
\hline- & - & - & - & $-Y / \Delta 9 V T_{G}$ & $\circ$ & $\circ$ & $\circ$ & $A_{r}$ \\
\hline- & - & - & - & $r / 09911$ & $-\circ / 1 \circ \Delta \circ 1$ & - $90 \wedge 1 \mathrm{r}$ & O/ TYVA & $A_{\psi}$ \\
\hline- & - & - & - & $\circ$ & $\circ$ & $\circ$ & $\circ$ & $\mathrm{A}_{\Delta}$ \\
\hline- & - & - & - & 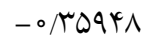 & $-0 / 0010 \mu$ & $-\circ / \Delta V Y \Lambda \Lambda$ & 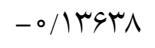 & $\mathrm{A}_{4}$ \\
\hline- & - & - & - & $\circ$ & $\circ$ & 。 & $\circ$ & $\mathrm{A}_{\vee}$ \\
\hline - & - & - & - & - & - & -/19H人 & & $\mathrm{A}_{\wedge}$ \\
\hline سM & $\circ$ & $0 / 19990$ & $\circ$ & - & - & - & - & L-Skewness \\
\hline.$/ 19 \mathrm{~V}$ & $\circ$ & $\circ / 10 \circ \circ 4$ & D MTYGG & - & - & - & - & L-Kurtosis \\
\hline
\end{tabular}

$\mathrm{K}_{\mathrm{N}}=-4 / 9 \cdot\left[\mathrm{P}^{\circ / 14}-(1-\mathrm{P})^{0 / 14}\right]$

$[\mathrm{IV}]$

$\mathrm{K}_{\mathrm{P}}=\frac{\mathrm{r}}{\mathrm{g}} \cdot\left[\left(\frac{\mathrm{g}}{4} \cdot\left(\mathrm{K}_{\mathrm{N}}-\frac{\mathrm{g}}{4}\right)+1\right)^{\mathrm{r}}-1\right]$

$\mathrm{K}_{\mathrm{G}}=-\frac{\sqrt{4}}{\mathrm{P}} \cdot\left[0 / \operatorname{QVVr}+\mathrm{LN}\left(\mathrm{LN}\left(\frac{1}{1-\mathrm{P}}\right)\right)\right]$

در اين رابطهها، P تابع تجمعى احتمال و g ضريب جـولكى

است. براى تخمين احتمال تجمعى در رابطه VI و 19 بهترتيـب

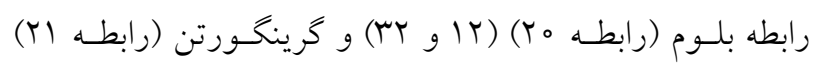

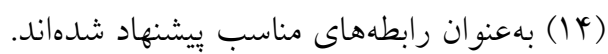

$P=\frac{i-\circ / r v Q}{n+o / r \omega}$

$\mathrm{P}=\frac{\mathrm{i}-\circ / \mathrm{kr}}{\mathrm{n}+\circ / \mathrm{rr}}$

در رابطه مب و آT، n تعـداد داده مشـاهدهاى و i رتبـه داده،

براى حالتى كه دادهها براساس ترتيب كاهشـى مرتـب شـدهانـد،

مدل جند مكانى خودهمبسته مرتبه اول

بارش سالانه در جند مكان را با مدل جند مكسانى خودهمبسته مرتبه اول مىتوان شبيهسازى نمود (Uا و وس). اين مدل (رابطـهـ
$\mathrm{X}_{\mathrm{T}}=\mu+\mathrm{K} . \sigma$

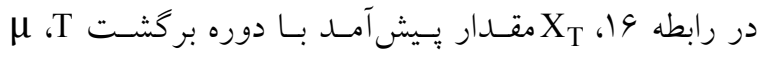

ميانخين و م انحراف معيار جامعه است. در اين رابطه K عامـل فراوانى و تابعى از دوره بركشـت و وِارامترهـاى توزيـع اسـت.

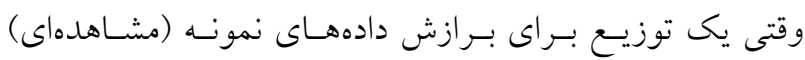

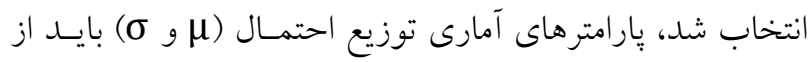
دادههـاى نمونــه بـــرآورد شـوند. بـين دادههــاى نمونـهـ و ارقـام (محاسبهايى) حاصل از تابع توزيع احتمال ممكن است اختلاف وجود داشته باشد. هدف اصلى روشهاى برآورد يارامتر توزيع،

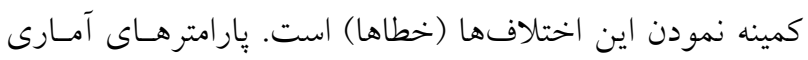
توزيع احتمال با يكى از روشهاى گشتاور، بيشينه درستنمايى

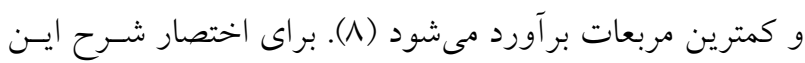
روشها ارائه نشده است و درصـورت نيـاز مسىتـوان بـه منبـع شماره 1 مراجعه نمود. در اين تزخوهش براى تخمين عامل فراوانى سه توزيع نرمال، لـوقنرمـال دو و سـه يـار امترى از رابطـه VIV (19)، دو توزيـع

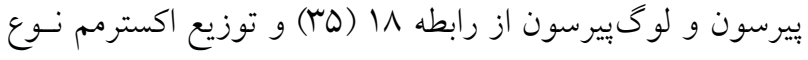
يك (كامبل) از رابطه 19 (F (1) استفاده شد. 
$\mathrm{B} \cdot \mathrm{B}^{\mathrm{T}}=\mathrm{S}_{\mathrm{o}}-\mathrm{A} \cdot \mathrm{S}_{\mathrm{o}} \cdot \mathrm{A}^{\mathrm{T}}$

$[\mathrm{rV}]$

مـاتريس واريـانس و كوواريـانس دادههـاى مشـاهدهاى S.

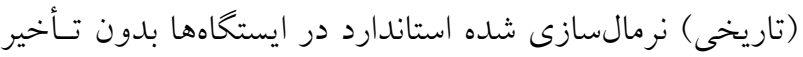
زمانى (Lago) و I S ماتريس كوواريـانس دادهــاى مشـاهدهاى

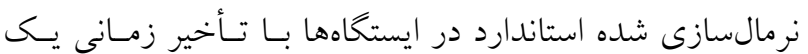

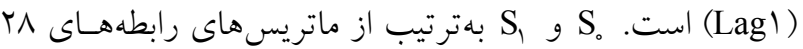

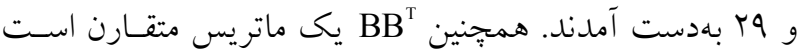
كه از روش جولسكى (Y) براى تجزيه آن به مـاتريسهـاى B و

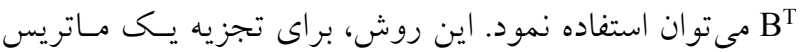

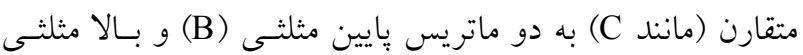

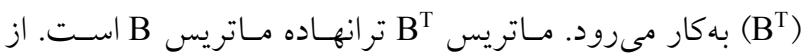

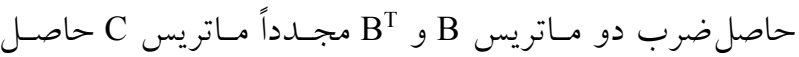

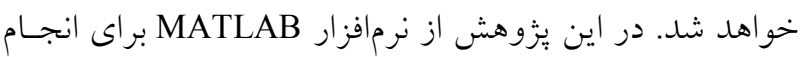
محاسبات عددى استفاده شد.

$$
S_{\circ}=\left[\begin{array}{cccc}
\operatorname{Var}\left(Z_{t}^{\prime}\right) & \operatorname{Cov}\left(Z_{t}^{\prime}, Z_{t}^{r}\right) & \ldots & \operatorname{Cov}\left(Z_{t}^{\prime}, Z_{t}^{n}\right) \\
\operatorname{Cov}\left(Z_{t}^{r}, Z_{t}^{\prime}\right) & \operatorname{Var}\left(Z_{t}^{r}\right) & \ldots & \operatorname{Cov}\left(Z_{t}^{r}, Z_{t}^{n}\right) \\
\vdots & \vdots & \vdots & \vdots \\
\operatorname{Cov}\left(Z_{t}^{n}, Z_{t}^{\prime}\right) & \operatorname{Cov}\left(Z_{t}^{n}, Z_{t}^{r}\right) & \ldots & \operatorname{Var}\left(Z_{t}^{n}\right)
\end{array}\right]
$$

$S_{1}=\left[\begin{array}{cccc}\operatorname{Cov}\left(Z_{t}^{\top}, Z_{t-1}^{1}\right) & \operatorname{Cov}\left(Z_{t}^{\prime}, Z_{t-1}^{r}\right) & \ldots & \operatorname{Cov}\left(Z_{t}^{1}, Z_{t-1}^{n}\right) \\ \operatorname{Cov}\left(Z_{t}^{r}, Z_{t-1}^{\prime}\right) & \operatorname{Cov}\left(Z_{t}^{r}, Z_{t-1}^{r}\right) & \ldots & \operatorname{Cov}\left(Z_{t}^{r}, Z_{t-1}^{n}\right) \\ \vdots & \vdots & \vdots & \vdots \\ \operatorname{Cov}\left(Z_{t}^{n}, Z_{t-1}^{\prime}\right) & \operatorname{Cov}\left(Z_{t}^{n}, Z_{t-1}^{r}\right) & \ldots & \operatorname{Cov}\left(Z_{t}^{n}, Z_{t-1}^{n}\right)\end{array}\right]$ در اين يزوهش سرىهاى زمانى دادههاى بارش سـالانه هشـت

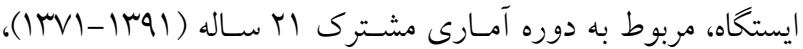

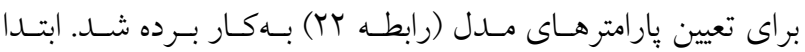

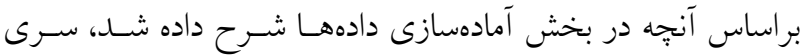

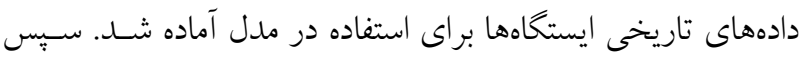

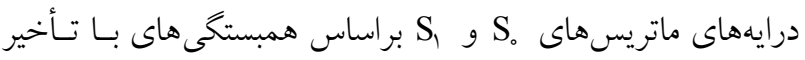

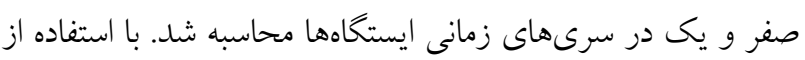

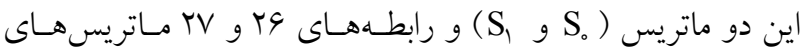

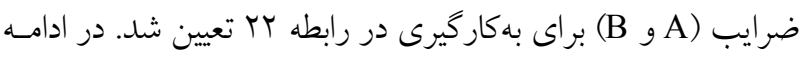
بردار متغيرهاى تصادفى (V) با استفاده از ابزار توليد علد تصـادفى
(TY) بهوسيله متلس (TQ) ارائه شده است.

$Z_{t}=A \cdot Z_{t-1}+B \cdot V_{t}$

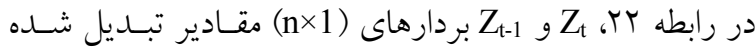

متغير (بارش سالانه) با ميانخين صفر براى سالهـاى t و و و ل

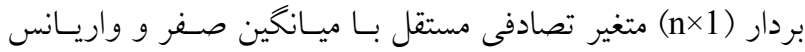
واحد (يك) است. Z و V داراى توزيع نرمـال هستـند، همجنـسين

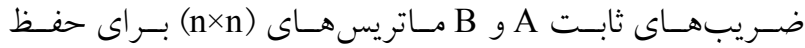
خودهمبسـتخى و همبسـتـى متقابــل (Cross Correlation)

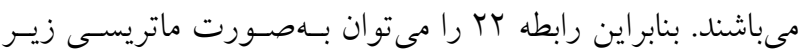

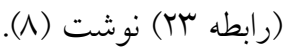

$\left[\begin{array}{c}z_{t}^{\prime} \\ \vdots \\ z_{t}^{n}\end{array}\right]=\left[\begin{array}{ccc}a_{1,1} & \cdots & a_{1, n} \\ \vdots & \ddots & \vdots \\ a_{n, 1} & \cdots & a_{n, n}\end{array}\right] \cdot\left[\begin{array}{c}z_{t-1}^{\prime} \\ \vdots \\ z_{t-1}^{n}\end{array}\right]+\left[\begin{array}{ccc}b_{1,1} & \cdots & b_{1, n} \\ \vdots & \ddots & \vdots \\ b_{n, 1} & \cdots & b_{n, n}\end{array}\right] \cdot\left[\begin{array}{c}v_{t}^{\prime} \\ \vdots \\ v_{t}^{n}\end{array}\right]$

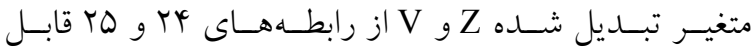
محاسبه مىباشند.

$Z_{t}^{n}=\frac{\left(x_{t}^{n}-\bar{x}_{t}^{n}\right)}{\left(S_{x}\right)_{t}^{n}}$

$\mathrm{V}_{\mathrm{t}}^{\mathrm{n}}=\frac{\left(\mathrm{e}_{\mathrm{t}}^{\mathrm{n}}-\overline{\mathrm{e}}_{\mathrm{t}}^{\mathrm{n}}\right)}{\left(\mathrm{S}_{\mathrm{e}}\right)_{\mathrm{t}}^{\mathrm{n}}}$

در روابط متغير تصادفى مستقل در زمان t

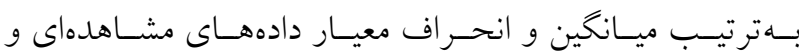
ميانخين و انحر اف معيـار متغيـر تصـادفى مسـتقل

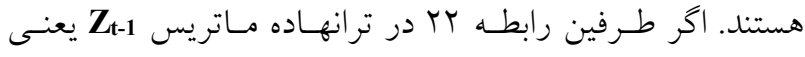

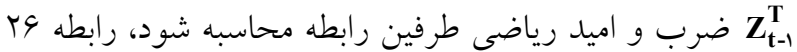

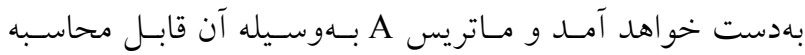

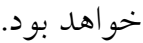
$\mathrm{A}=\mathrm{S}_{1} \cdot \mathrm{S}_{\circ}^{-1}$

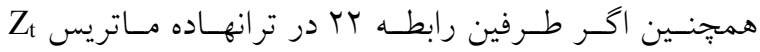

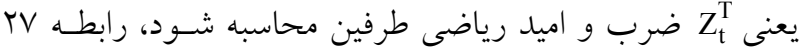
حاصل مىشود و ماتريس B از آن قابل محاسبه خواهد بود. 
مشاهدات است. توانايى مدل ازنظر توليد سـرى زمـانى درصـورتى

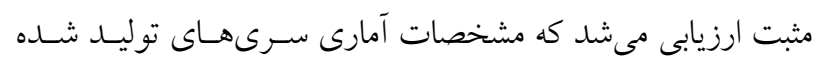
توسط مدل مشابه خواص آمارى سرى زمانى ثبت شــده (تـاريخى)

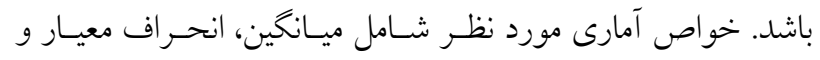

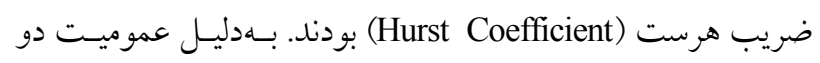
آماره اول در ادامه فقط ضريب هرست شرح داده شده است.

\section{ضريب هرست}

اين ضريب براى سنجش حافظـه بلندمـــت يـى سـرى زمـانى

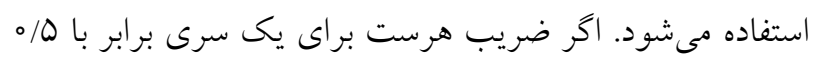

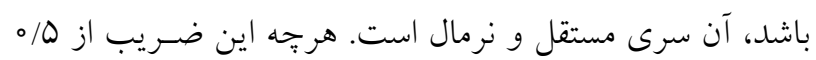

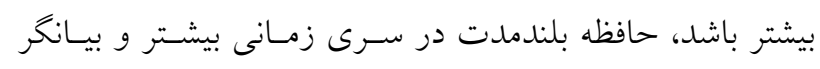

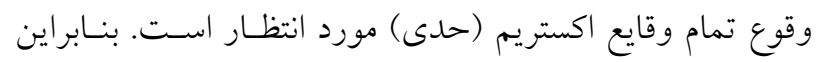

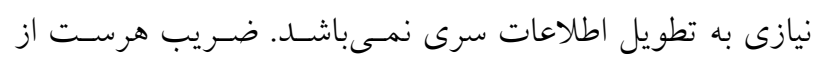

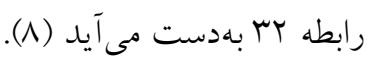
$\mathrm{H}=\frac{\log (\mathrm{R} / \sigma)}{\log (\mathrm{n} / \mathrm{r})}$

در رابطه بr. n تعداد دادهها در سرى زمـانى و م انحـراف معيار سرى است. همجنين R برابر با تفاوت بين بيشترين مقدار

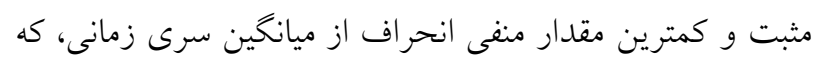
بهصورت تجمعى محاسبه شدهاند (Sn

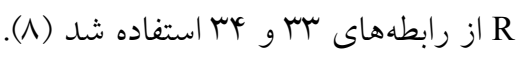

$\mathrm{S}_{\mathrm{n}}=\sum_{\mathrm{k}=1}^{\mathrm{n}}\left(\mathrm{x}_{\mathrm{k}}-\overline{\mathrm{x}}\right)$

$\mathrm{R}=\mathrm{S}_{\max }-\mathrm{S}_{\min }$

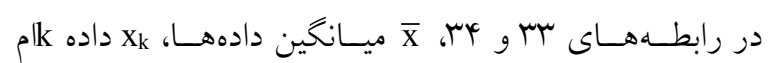

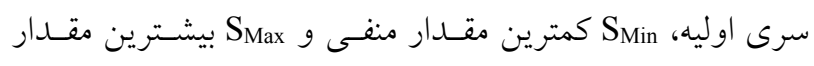

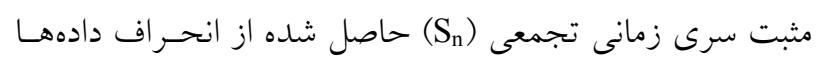
از ميانخين است.

نتايج و بحث مشخصات آمارى و نتايج بررسى كمسى و كيفى سـرى زمـانى
در صـفحه كســترده اكسـل (Random Number Generation)

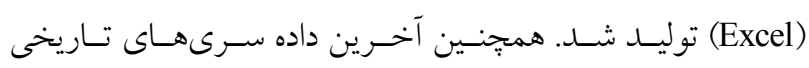

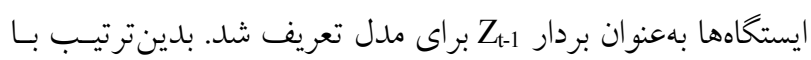

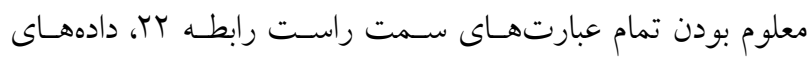

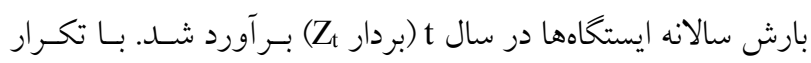

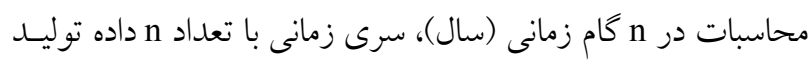

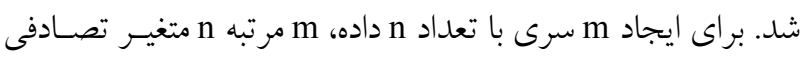

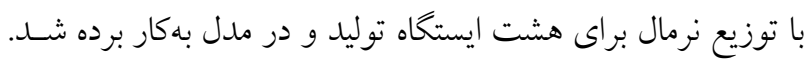

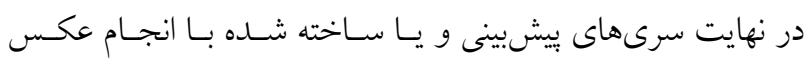

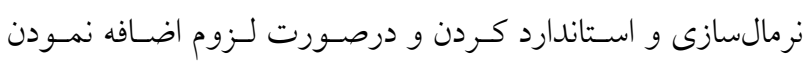
روندهاى قطعى، به دادهاى واقعى تبديل شدند (^).

ارزيابى مدل

براى ارزيابى دقت مدل در بيشبينى مقدار متغير (بارش سالانه)

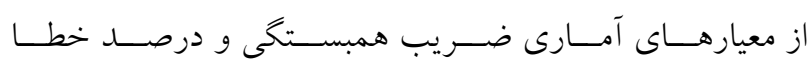
(Volume Error in Percent (\%VE)) همبستخى نشاندهنده ميزان همبستخى بين مقادير بـر آورد شـــه

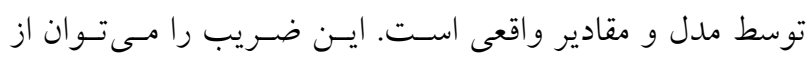

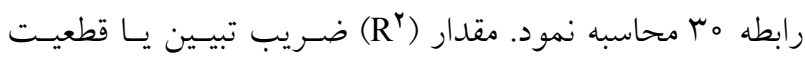
ناميده مىشود. براى استفاده (Coefficient of Determination) از معادلات ركرسيون در هيدرولوزى كمينه مقدار قابل قبول Rـ

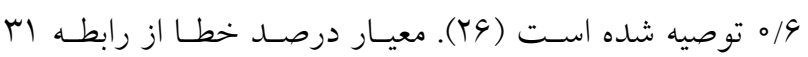
بهدست مى آيد. مقدار كمتر اين آماره، نشاندهنده عملكرد بهتر مدل است (ᄉ). $\mathrm{R}=\frac{\sum_{\mathrm{i}=1}^{\mathrm{n}}\left(\left(\mathrm{Z}_{\text {obs }}-\overline{\mathrm{Z}}_{\text {obs }}\right) \cdot\left(\mathrm{Z}_{\text {est }}-\overline{\mathrm{Z}}_{\text {est }}\right)\right)}{\sqrt{\sum_{\mathrm{i}=1}^{\mathrm{n}}\left(\mathrm{Z}_{\mathrm{obs}}-\overline{\mathrm{Z}}_{\text {obs }}\right)^{r} \cdot \sum_{\mathrm{i}=1}^{\mathrm{n}}\left(\mathrm{Z}_{\text {est }}-\overline{\mathrm{Z}}_{\text {est }}\right)^{r}}}$

$\% \mathrm{VE}=\frac{\sum_{\mathrm{i}=1}^{\mathrm{n}}\left|\frac{\mathrm{Z}_{\text {obs }}-\mathrm{Z}_{\mathrm{est}}}{\mathrm{Z}_{\text {obs }}}\right|}{\mathrm{n}}$

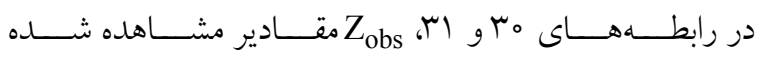
(واقعى)، شده (خروجى مدل)، 


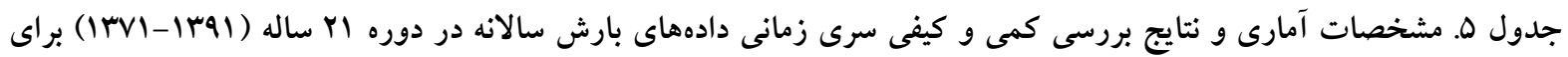
ايستخاههاى انتخاب شده در منطقه كردستان

\begin{tabular}{|c|c|c|c|c|c|c|c|c|c|}
\hline \multicolumn{8}{|c|}{ ايستخاه (شماره) } & \multirow{3}{*}{\multicolumn{2}{|c|}{ شرح }} \\
\hline زرينه - ا & سردشت & سقز & سندج & روانسر & مريوان & قروه ق & بيجار & & \\
\hline$(\Lambda)$ & $(v)$ & (9) & $(\Delta)$ & $(\boldsymbol{\varphi})$ & $(r)$ & $(Y)$ & (1) & & \\
\hline$r 90$ & AVG & YOV & rar & DIT & $9 r_{0}$ & MyY & Tr人 & يانخين بارش (mm) & \\
\hline$\Lambda 9 / r$ & $r \circ r / 1$ & $1 \mathrm{rV} / 0$ & $99 / \mathrm{V}$ & $\mid K T / 9$ & $r \mu V / r$ & $V G / T$ & $V \Psi / 4$ & نحراف معيار (mm) & \\
\hline $0 / r$ & $\circ / 1$ &.$/ 9$ & $\circ / 0$ & $\circ / 4$ & $0 / r$ & 1/or & $\circ / 4$ & جولكى & \\
\hline $0 / 91$ &.$/ 91$ & $\circ / N Q$ & $\circ / N V$ & $0 / 91$ & $\circ / V^{4}$ & $0 / 94$ & O/NT & ضريب هرست & \\
\hline 919 & $I T \circ Y$ & 19. & 940 & VM & IFY & $\Delta M$ & $01 V$ & بيشينه دادهها (mm) & آزمون كرابز \\
\hline r19 & TMU & TVY & rmo & rmy & $\Delta \circ \Delta$ & TrY & 191 & كمينه دادهها (mm) & (تعيين داده \\
\hline 911 & lorr & $\Lambda \Lambda \Delta$ & 991 & 191 & 1919 & $\Delta \Delta \wedge$ & $\Delta \& V$ & مرز بحرانى بالا (mm) & يرت)، ريسك \\
\hline YM & GVV & TIV & $r \circ \Lambda$ & rVV & 499 & $r \circ r$ & 194 & مرز بحر انى پيايين (mm) & اشتباه در حذف \\
\hline ن ارد & ن ارد & ن ارد & ن ارد & 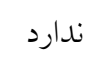 & 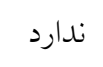 & ن ارد & 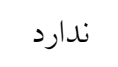 & تفسير آزمون (داده يرت) & داده Q/ درصد \\
\hline$-0 / 44$ & $-0 / 19$ & $-0 / \wedge 9$ & $-1 / \mu c$ & $-T / T r$ & $-1 / \mathrm{VN}$ & $-0 / K^{k}$ & $-r / 9 \Lambda$ & آماره آزمون (قبل از حذف روند) & \\
\hline $\pm 1 / 99$ & $\pm 1 / 99$ & $\pm 1 / 99$ & $\pm 1 / 99$ & $\pm 1 / 94$ & $\pm 1 / 99$ & $\pm 1 / 99$ & $\pm 1 / 99$ & مقدار بحرانى (در سطح ه./) & \\
\hline همخن & همخن & ل مaكن & همخن & ناهمخن & همخن & همخن & ناهمكن & تفسير آزمون (دادهها) & \\
\hline$\% / 01$ & $-o / 4 y$ & $\circ \%$ & $0 / 49$ & $\circ \%$ & $\circ \%$ 。 & $\%$ & $-1 / \pi r$ & آماره آزمون (بعد از حذف روند) & \\
\hline همخن & همخن & همخن & همخن & همخن & همخن & همخن & همخن & تفسير آزمون (دادهها) & \\
\hline$-1 / A V$ & $-1 / \Gamma \Lambda$ & $-1 /{ }^{2}$ & $-Y / T V$ & $-Y / T Q$ & $-T / \mu r$ & $-\circ / M^{4}$ & $-\circ / \pi \Delta$ & آماره آزمون & \\
\hline $\pm 1 / 99$ & $\pm 1 / 99$ & $\pm 1 / 99$ & $\pm 1 / 99$ & $\pm 1 / 99$ & $\pm 1 / 99$ & $\pm 1 / 99$ & $\pm 1 / 99$ & مقدار بحر انى (در سطح ه.) & \\
\hline 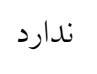 & 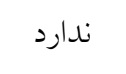 & 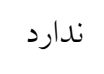 & دارد & دارد & 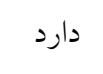 & 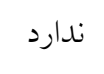 & 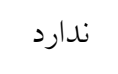 & تفسير آزمون (در سطح ه/\%) & ارمون استيرمن \\
\hline $0 / q_{V}$ & $-0 / Y r$ & $\circ / \mu_{0}$ & $0 / 19$ & $0 / 09$ & $-0 / \% \mathrm{~V}$ & $0 / T r$ & $0 / \mu r$ & آماره آزمون (بعد از حذف روند) & \\
\hline 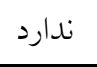 & 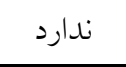 & 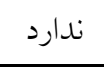 & 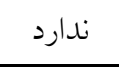 & 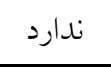 & 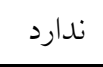 & 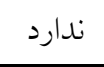 & 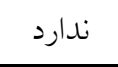 & تفسير آزمون (در سطح ه.٪) & \\
\hline
\end{tabular}

در سطح اعتماد هل درصد معنىدار نبود. رونســ سـرى دادههـاى

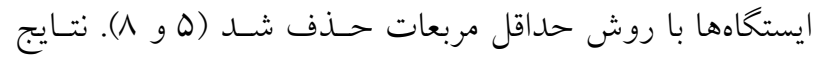

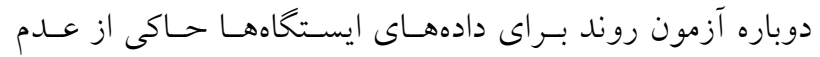

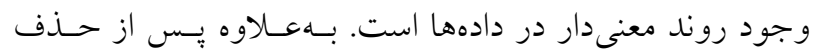

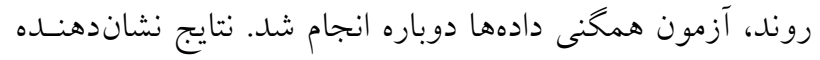

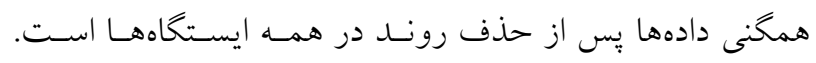

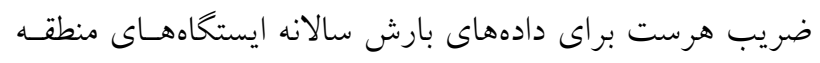

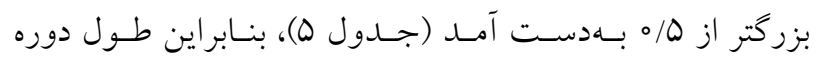

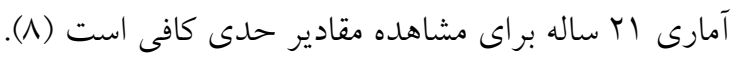

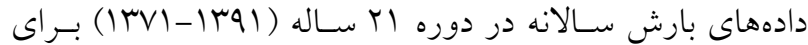

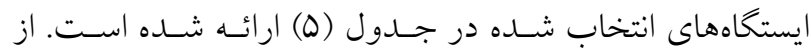
بررسى جدول (ه) مشاهده مى شود در همه ايستخاههـا، سـرى إنى

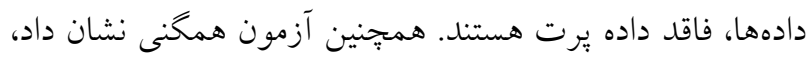

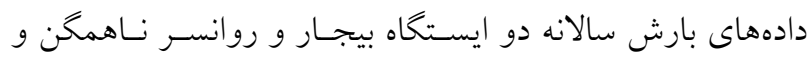

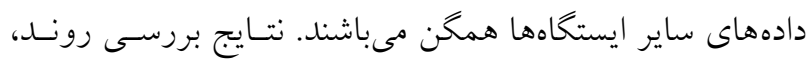
حاكى از وجود روند كاهشى در مقدار بارش سالانه سه ايستخاه

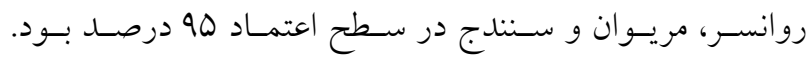

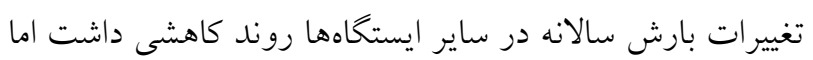


شد. از شكل (r) مشاهده مىشـود كشـتاورهاى دادههـاى بـارش

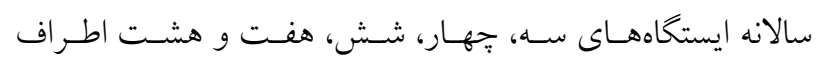

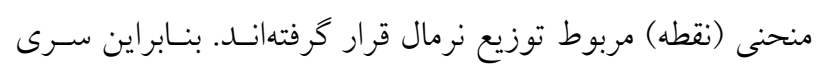

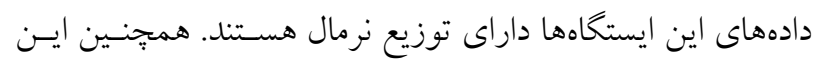

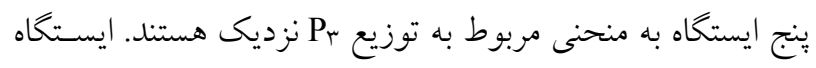

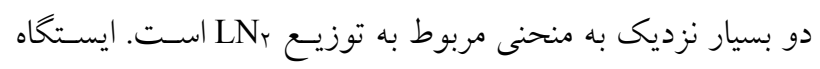

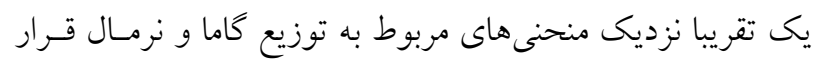

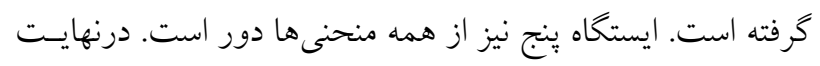

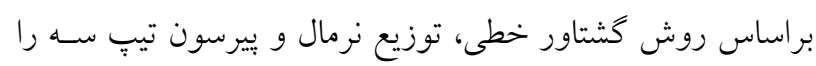

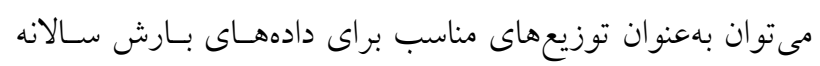
منطقه درنظر كرفت.

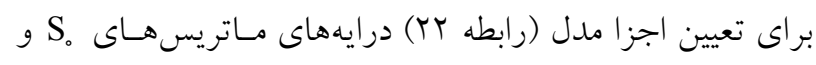

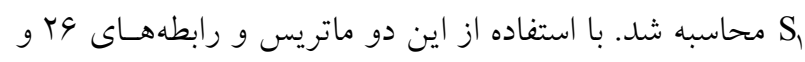

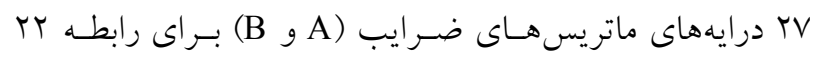

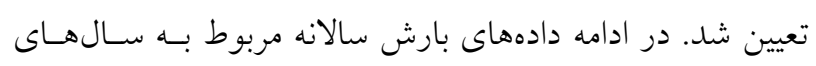

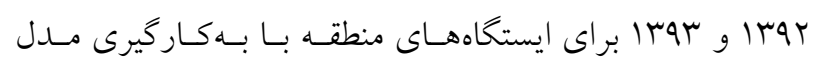

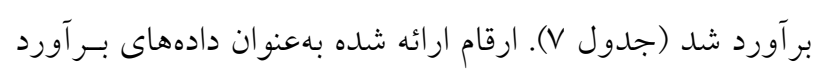

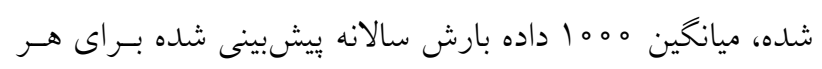

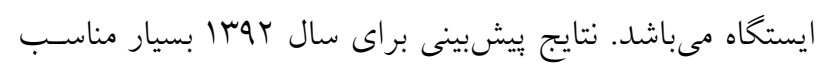
بود. بهطورى كه درصد خطا در همه ايستخاهها به غير از ايستخاه

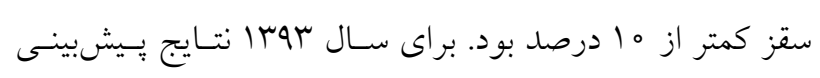
دقت كمترى نسبت به هـيشبينى سـال rar إ داشـت. ميـانخين

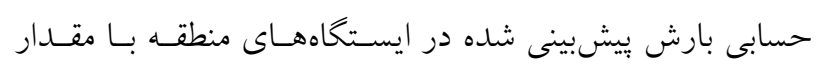

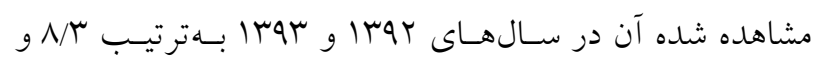

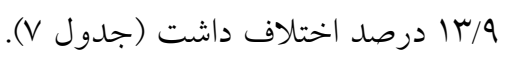

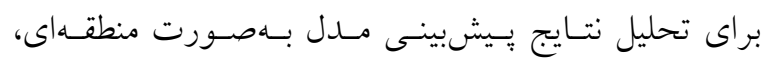

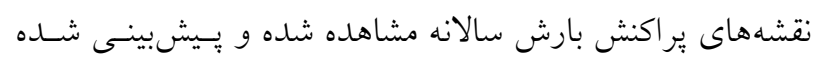

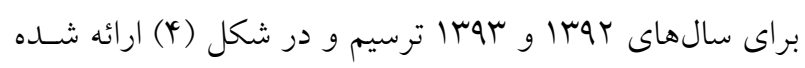
است. از اين شكل مشاهده مىشود نقشههاى واقعى و بيشبينى

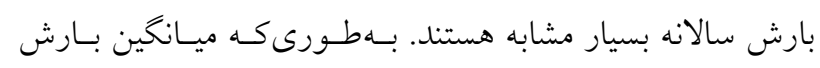

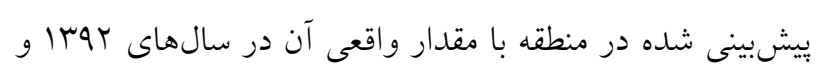

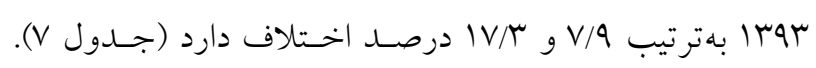

همانطوركه بيان شد، دادههايى كه بـراى مــلـسـازى خنـــ مكانى خودهمبسته مرتبـه اول اسـتفاده مسى شــوند، بايســ نرمـال

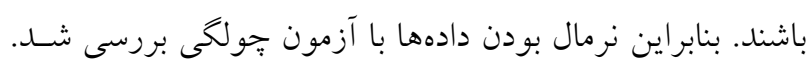

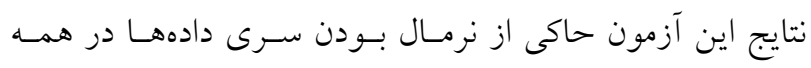

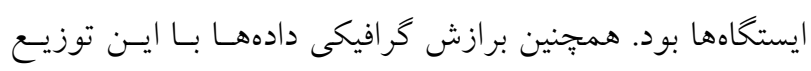

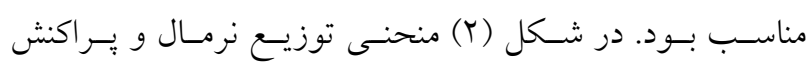

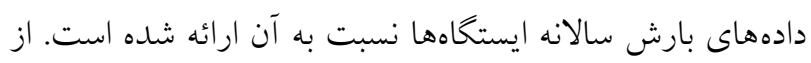
اين شكل مشاهده مىشود براى هر هشت ايستـاهاه، بـيش از 90 درصد نقاط نمايش دهنده بارش سالانه در محدوده باند اطمينان

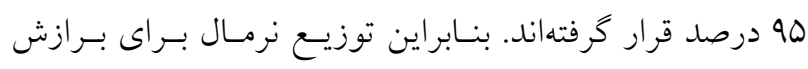

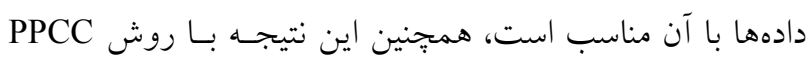

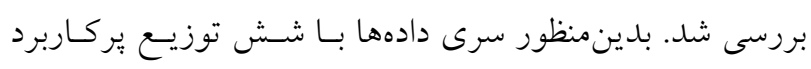

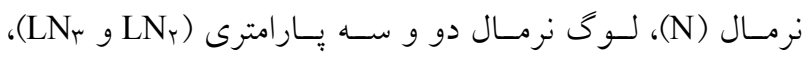

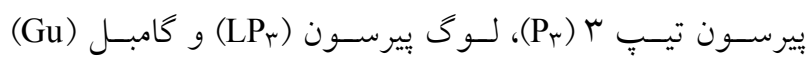

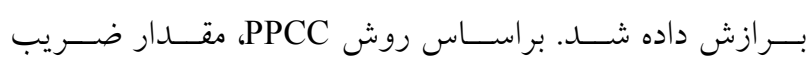

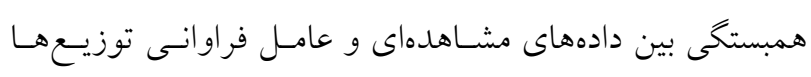

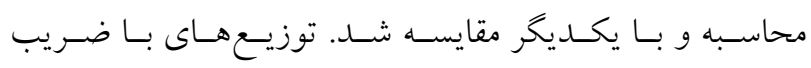

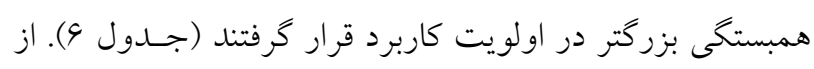

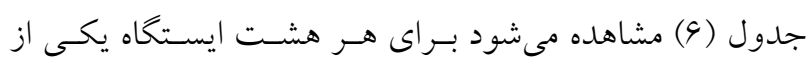

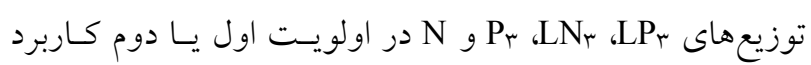

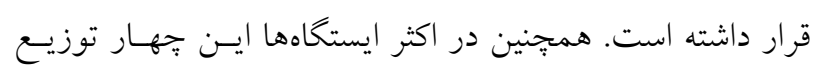

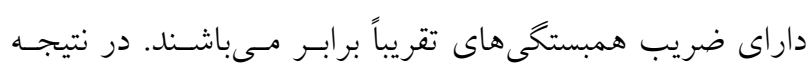

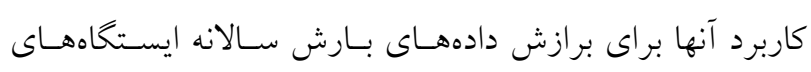
منطقه بيشنهاد مىشود.

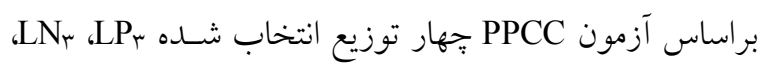

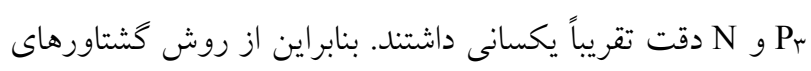
خطى نيز براى ارزيابى توزيعها و انتخاب توزيع برتر استفاده شد.

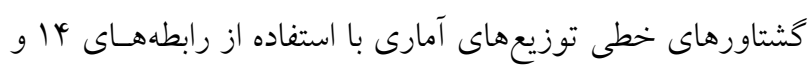

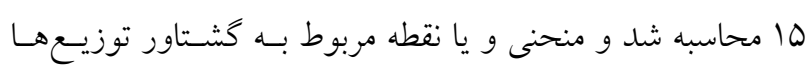

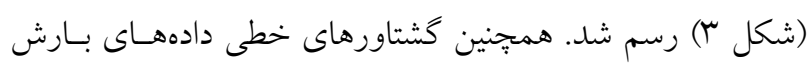

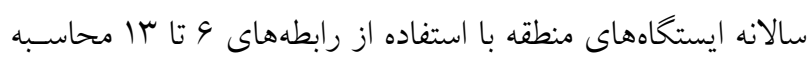

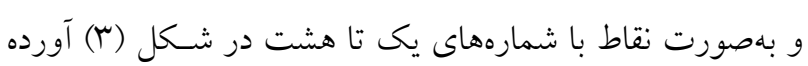



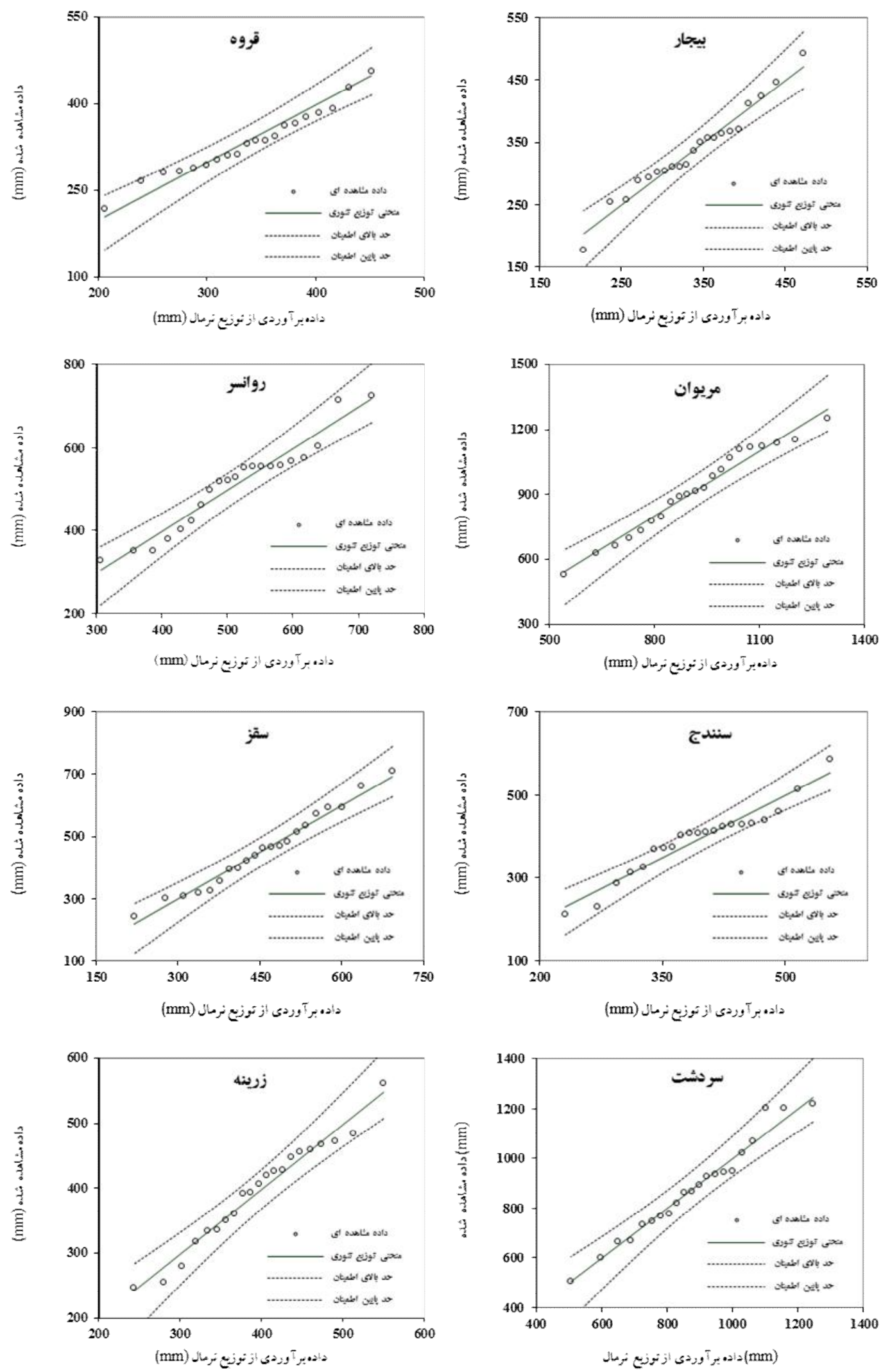

شكل r. ير اكنش دادههاى بارش سالانه ايستخاهها نسبت به منحنى توزيع نرمال و حدود اطيمنان بالاو وِايين آن در سطح اطمينان هو درصد 
جدول 9. ضريبهاى همبستخى بين دادههاى بارش سالانه مشاهدهاى و عامل فراوانى توزيعها در ايستخاههاى منطقه

\begin{tabular}{|c|c|c|c|c|c|c|}
\hline \multicolumn{6}{|c|}{ توزيعها } & \multirow{2}{*}{ يستخاه (شماره) } \\
\hline 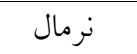 & لوگ نرمال Y يارامترى & لو گ نرمال ب يارامترى & بيرسون & لوى يُيرسون & كامبل & \\
\hline 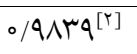 &.$/ 999 \Delta^{[9]}$ & $\circ / 9 \wedge r \Delta^{[r]}$ & $0 / 9 \wedge 4 q^{[1]}$ & $\circ / 9 \vee G \mu^{[*]}$ & $0 / 9 V<Y^{[0]}$ & بيجار (1) \\
\hline - $/ 909 \mu^{[9]}$ & $0 / 9 \wedge \wedge \mu^{[*]}$ & $\circ /\left.9 \wedge 4\right|^{[r]}$ & $\circ / 99 \Delta V^{[0]}$ & $\circ / 91 M 1^{[r]}$ & $\circ / 99 \circ Y^{[1]}$ & قروه (Y) \\
\hline$\circ / 9 \wedge \wedge \mu^{[r]}$ & $\circ / 9 \vee V q^{[0]}$ & $\circ / 9 \wedge \vee Y^{[*]}$ & $\circ / 99 \circ \psi^{[r]}$ &.$/ 99 Y^{[1]}$ & $\circ / 90 \circ 4^{[9]}$ & مريوان (r) \\
\hline$\circ / 9 \vee \circ \Lambda^{[*]}$ & $0 / 999 \mu^{[0]}$ & $\circ / 9 V / 1^{[r]}$ & $\circ / 9 \mathrm{~V} / 0^{[r]}$ &.$/ 9 V 19^{[1]}$ & - /90YV $[8]$ & روانسر (†) \\
\hline$\circ / 99 \Delta V^{[r]}$ & o/grep[o] & 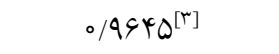 & $\circ / 9900^{[*]}$ & $0 / 9 V_{0} 1^{[1]}$ & $0 /\left.94\right|^{18]}$ & سنتدج (ه) \\
\hline $0 /\left.991\right|^{4[*]}$ & $\circ / 99 Y_{0}[r]$ &.$/ 9941^{[1]}$ & $\circ / 9 \wedge \wedge V^{[0]}$ & $0 / 994_{0}[r]$ & $\circ / 9 \wedge \Delta r^{[q]}$ & سقز (4) \\
\hline - /9MAYr $r^{[r]}$ & $\circ / 9 \wedge V V^{[*]}$ & $\circ / 99 \circ \mu^{[r]}$ & $\circ / 9 \wedge \vee q^{[0]}$ & $0 / 99 r_{0}[1]$ & $\circ / 9 V Y q^{[9]}$ & سردشت (V) \\
\hline$\circ / 9 \wedge 9 Q^{[r]}$ & $\circ / 9 V \forall \&[0]$ & $\circ / Q \wedge \Delta \psi^{[*]}$ & $\circ / 9 \wedge V_{0}[1]$ & $\circ / 9 \wedge \& q^{[r]}$ & $\circ / 9 Q V)^{[8]}$ & زرينه (ی) \\
\hline
\end{tabular}

اولويت كاربرد توزيع بهصورت توان، داخل كروشه و در گوشه سمت راست آن نوشته شده است.

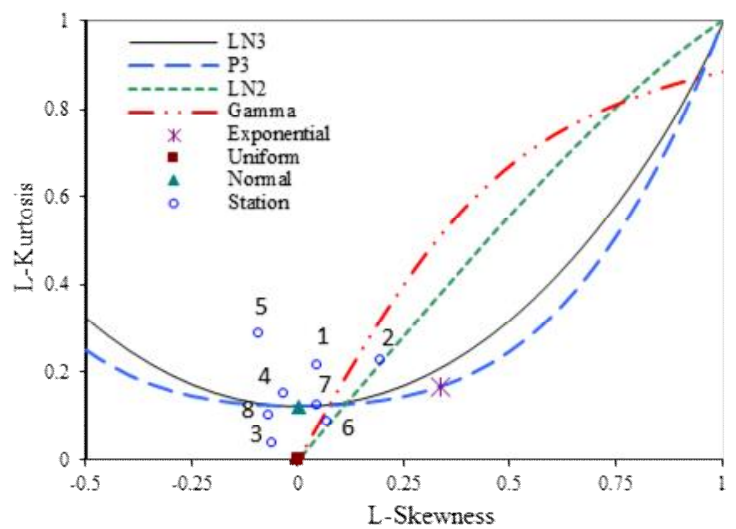

شكل ז. گشتاورهاى خطى توزيعهاى آمارى و گثتاور سرىهاى زمانى ايستخاههاى منطقه (مشخص شده با شماره ايستخاه)

جدول V. دادهاى بارش سالانه برآورد شده و مشاهده شده براى ايستخاههاى منطقه

\begin{tabular}{|c|c|c|c|c|c|c|}
\hline \multicolumn{3}{|c|}{ سال rar } & \multicolumn{3}{|c|}{ بارش سال Mar Mar } & \multirow[b]{2}{*}{ ايستخاه } \\
\hline درصد خطا & $\begin{array}{c}\text { بر آورد شده } \\
\text { (mm) }\end{array}$ & مشاهده شده & درصد خطا & $\begin{array}{c}\text { بر آورد شده } \\
\text { (mm) }\end{array}$ & مشاهده شده & \\
\hline$r G / r$ & TDQ & TAY & $-10 \%$ & Met & rNI & بيجار (1) \\
\hline$r \Delta / \varphi^{c}$ & maq & TQ。 & $Y / V$ & Mro & ros & قروه (Y) \\
\hline$\circ / 0$ & V99 & $\mathrm{V} 90$ & $10 / \mathrm{V}$ & 909 & $\wedge r$ & مريوان (س) \\
\hline$T Q / \circ$ & pyt & $r \Delta \Delta$ & $9 / 1$ & 199 & $4 \& V$ & روانسر (4) \\
\hline$r V / r$ & rov & rA。 & $9 / 9$ & mes & Mls & سنندج (ه) \\
\hline $14 / 1$ & YOV & $r 01$ & $T Y / D$ & $Y \Delta \wedge$ & ra八 & سقز (9) \\
\hline$-\circ / r$ & NTr & rmq & $9 / 9$ & $\Lambda \Delta^{\circ}$ & $V V r$ & سردشت (V) \\
\hline$\mu_{\circ / \Lambda}$ & $Y \circ V$ & mI & $9 / 0$ & mvi & meq & زرينه (^) \\
\hline $1 \pi / 9$ & 4q4 & pry & $\Lambda / r$ & DIT & prr & ميانخين حسابى \\
\hline$I V / r$ & per & rVA & $V / 9$ & ror & YYo & ميانخين (خطوط همباران) \\
\hline
\end{tabular}




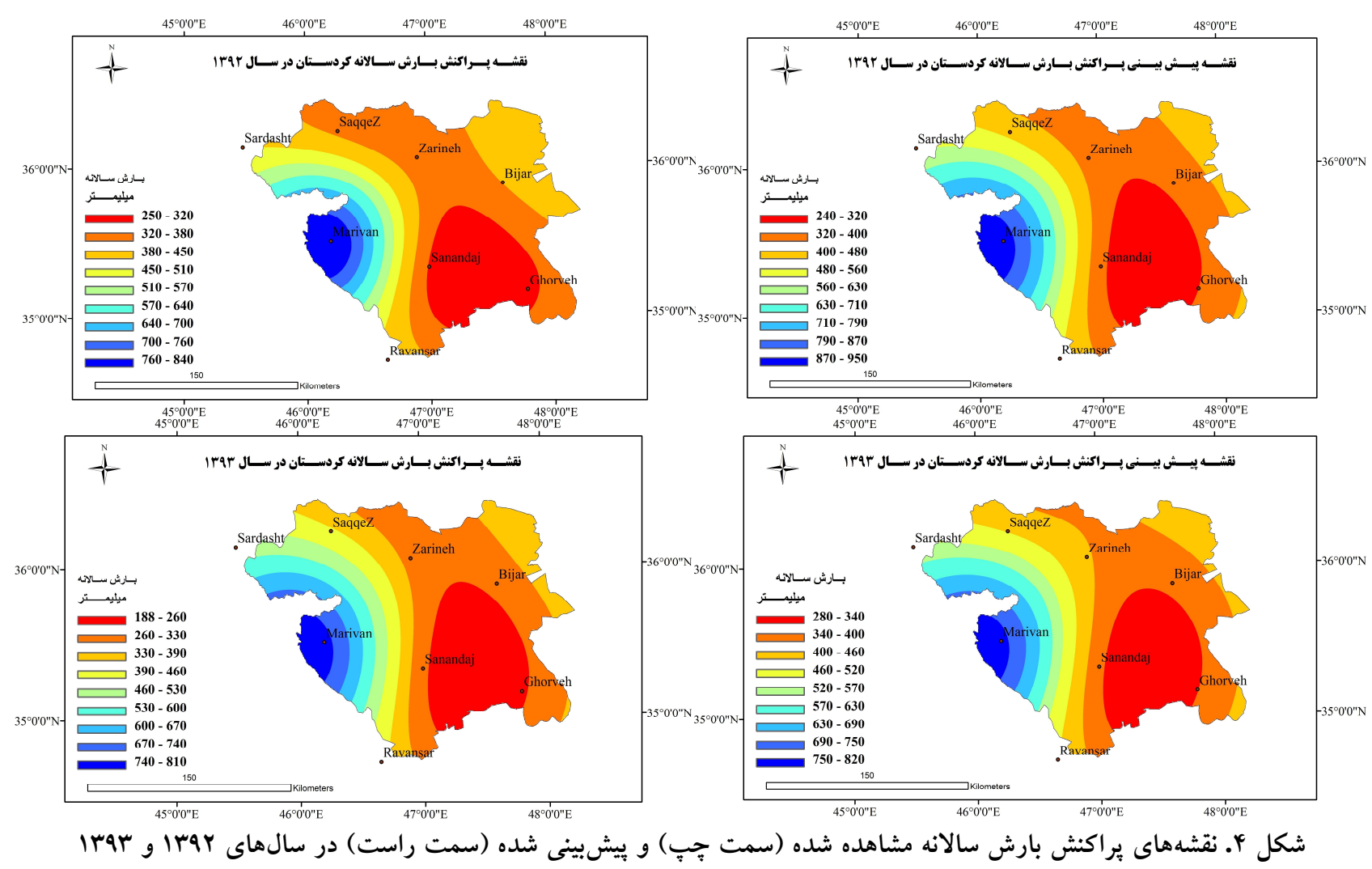

ضريب همبستخى و ميانخين درصد خطا بهدست آمده مسىتسوان كفت، مدل تدوين شده از توانايى بالايى براى بيشبينى مكانى زمانى بارش سالانه در منطقه برخودار است. در اين بخش تو انايى مدل از نظر توليد سرى زمانى ارزيابى شد.

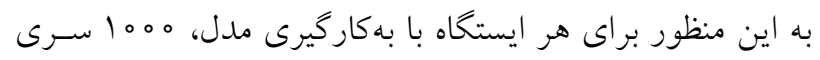

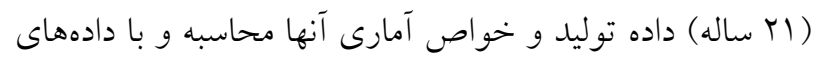
تاريخى مقايسه شد. مشخصات آمارى دادههـاى بـارش سـالانه

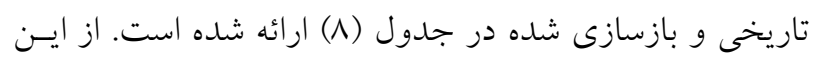

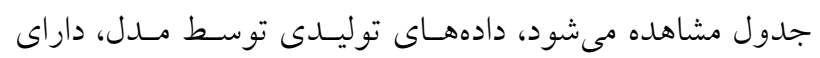
مشخصات آمارى مشابه با دادهاى تاريخى مى باشند. همرهنسين

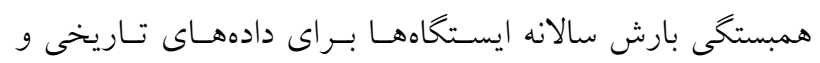

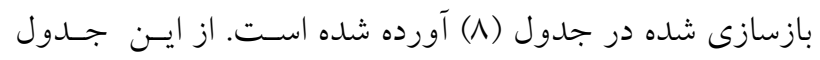

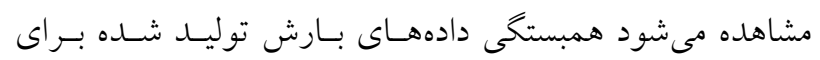

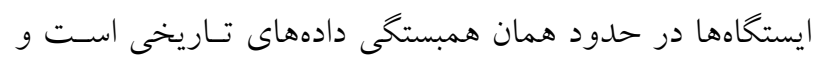

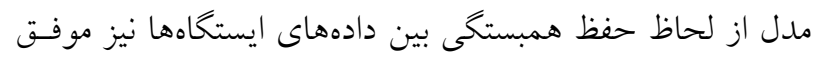
عمل نموده است.
اين مقدار خطا با مقدار مشابه آن، كه با ميانخين حسابى بهدست

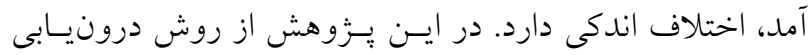
كريجينگ براى ترسيم منحنى همبارش و محاسبه ميانخين بارش

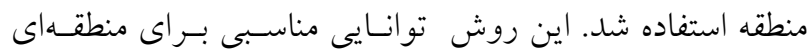

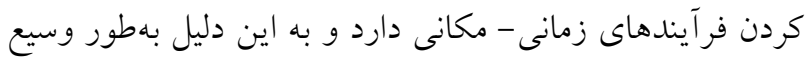
در زمينههاى محسيط زيست، اكتشـاف معـدن، نقشـهبــردارى و هيدرولوزى استفاده مى شود (N).

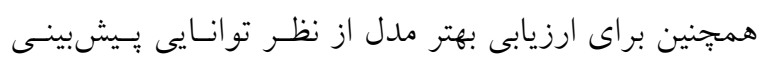

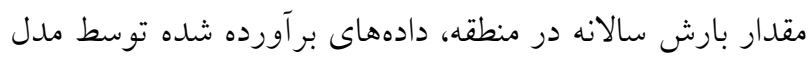

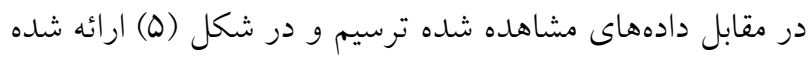

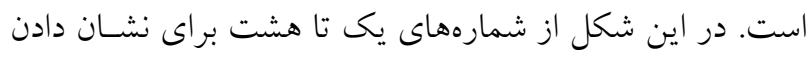

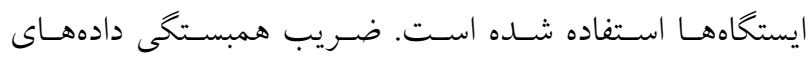

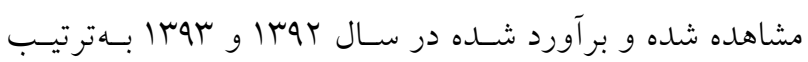

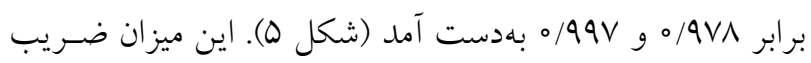

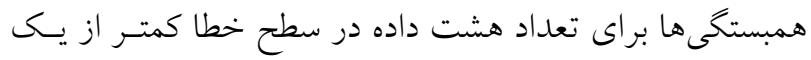

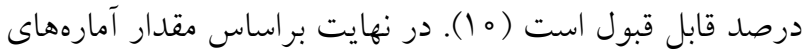



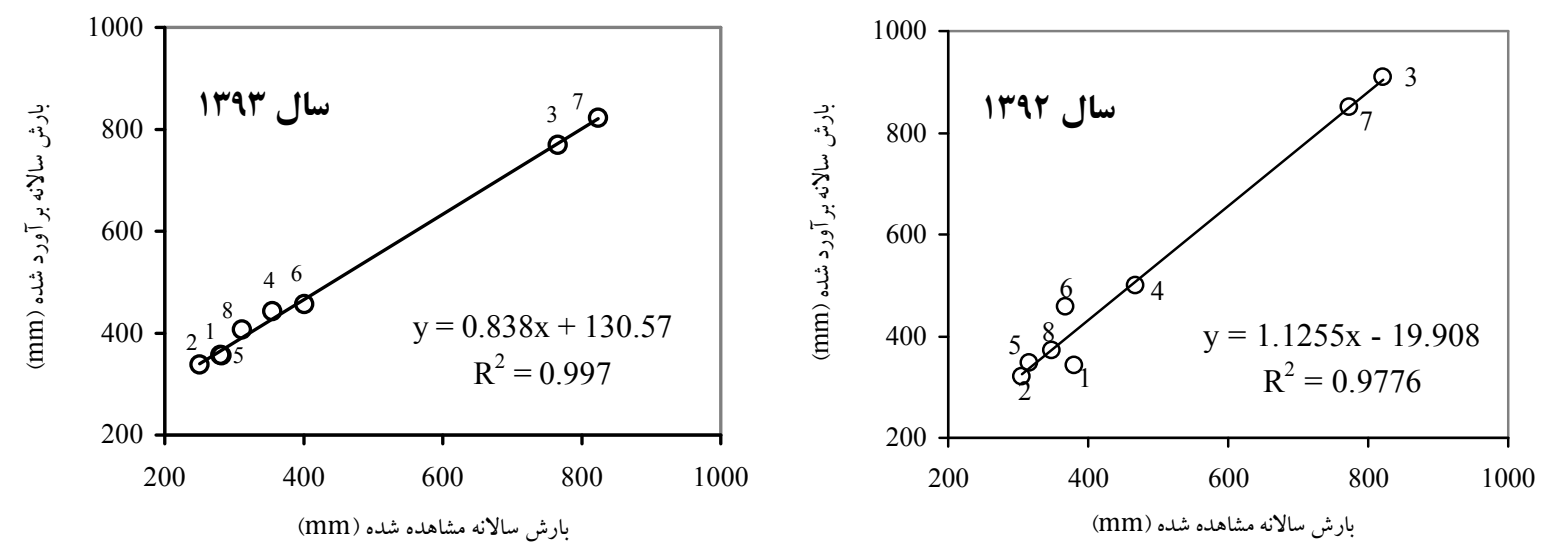

شكل ه. ميزان كارايى مدل جِند مكانى خودهمبسته مرتبه اول در برآورد بارش سالانه ايستخاههاى منطقه

جدول ^ـ مشخصات آمارى دادهاى بارش سالانه ثبت شده و توليد شده براى ايستخاهاى منطقه

\begin{tabular}{|c|c|c|c|c|c|c|c|c|}
\hline \multicolumn{8}{|c|}{ ضريب همبستكى } & \multirow{2}{*}{ ايستكاه (شماره) } \\
\hline زرينه (入) & سردشت (V) & سقز (4) & سنندج (ه) & روانسر (Y) & مريوان (r) & قروه (T) & بيجار (1) & \\
\hline $\begin{array}{l}\circ / N T \\
(\circ / N T)\end{array}$ & $\begin{array}{c}\circ / \Gamma V \\
(\circ / K V)\end{array}$ & $\begin{array}{c}\circ / V Y \\
(\circ / V 0)\end{array}$ & $\begin{array}{l}\circ / \Lambda \mu \\
(\circ / \Lambda \mu)\end{array}$ & $\begin{array}{l}\circ / \Delta Q \\
(\circ / \Delta \mu)\end{array}$ & $\begin{array}{l}\circ / 0 G \\
(\circ / 0 Y)\end{array}$ & $\begin{array}{l}\circ / V 9 \\
(\circ / V q)\end{array}$ & $\begin{array}{l}\text { 1/00 } \\
(1 / 00)\end{array}$ & بيجار (1) \\
\hline $\begin{array}{l}\circ / 09 \\
(0 / 09)\end{array}$ & $\begin{array}{l}0 / T \wedge \\
(0 / Y q)\end{array}$ & $\begin{array}{l}\circ / \Delta Q \\
(\circ / \Delta Q)\end{array}$ & $\begin{array}{l}\circ / \Lambda \circ \\
(\circ / \Lambda \circ)\end{array}$ & $\begin{array}{l}0 / 91 \\
(0 / 91)\end{array}$ & $\begin{array}{l}0 / \mathbb{E V} \\
(0 / \mathbb{A} \Lambda)\end{array}$ & $\begin{array}{l}1 / 00 \\
(1 / 00)\end{array}$ & & قروه (r) \\
\hline $\begin{array}{l}\circ / V Q \\
(0 / V I)\end{array}$ & $\begin{array}{l}\circ / V \wedge \\
(\circ / V 4)\end{array}$ & $\begin{array}{l}\text { O/AY } \\
(0 / \Lambda \circ)\end{array}$ & $\begin{array}{l}0 / \Lambda 1 \\
(0 / \Lambda 0)\end{array}$ & $\begin{array}{l}\circ / \Lambda Y \\
\left.(0 / \Lambda)^{\prime}\right)\end{array}$ & $\begin{array}{l}1 / 00 \\
(1 / 00)\end{array}$ & & & مريوان (r) \\
\hline $\begin{array}{l}0 / 94 \\
(0 / 09)\end{array}$ & $\begin{array}{l}0 / 99 \\
(0 / 91)\end{array}$ & $\begin{array}{l}\circ / N V \\
(\circ / N G)\end{array}$ & $\begin{array}{l}\circ / \Lambda Y \\
(0 / \Lambda Y)\end{array}$ & $\begin{array}{l}1 / \circ \circ \\
(1 / \circ \circ)\end{array}$ & & & & روانسر (4) \\
\hline $\begin{array}{l}\circ / \wedge \circ \\
(\circ / \mathrm{Q})\end{array}$ & $\begin{array}{l}0 / 9 V \\
(0 / 90)\end{array}$ & $\begin{array}{l}\circ / \mathrm{Vq} \\
(\circ / \mathrm{VA})\end{array}$ & $\begin{array}{l}1 / 00 \\
(1 / 00)\end{array}$ & & & & & سنادج (D) \\
\hline $\begin{array}{l}\circ / \Lambda \mu \\
(\circ / \Lambda \circ)\end{array}$ & $\begin{array}{l}0 / 99 \\
(0 / 70)\end{array}$ & $\begin{array}{l}1 / 00 \\
(1 / 00)\end{array}$ & & & & & & سقز (4) \\
\hline $\begin{array}{l}\circ / \mathrm{V} 0 \\
(0 / 91)\end{array}$ & $\begin{array}{l}1 / 00 \\
(1 / 00)\end{array}$ & & & & & & & سردشت (V) \\
\hline $\begin{array}{l}1 / 00 \\
(1 / 00)\end{array}$ & & & & & & & & زرينه (^) \\
\hline $\begin{array}{l}r 90 \\
(190)\end{array}$ & $\begin{array}{l}\text { AVG } \\
(A \vee G)\end{array}$ & $\begin{array}{l}Y Q V \\
(Y Q V)\end{array}$ & $\begin{array}{l}r q \mu \\
(r q \mu)\end{array}$ & $\begin{array}{l}D I Y \\
(D I Y)\end{array}$ & $\begin{array}{l}9 r_{0} \\
\left(9 r_{0}\right)\end{array}$ & $\begin{array}{l}\text { pyy } \\
(\text { pyy) }\end{array}$ & 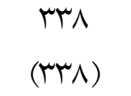 & ميانگين (mm) \\
\hline $\begin{array}{c}19 / r \\
(\Lambda \Lambda / 0)\end{array}$ & $\begin{array}{l}r \circ r / 1 \\
(19 V / 0)\end{array}$ & $\begin{array}{l}1 K V / 0 \\
(I r Y / 9)\end{array}$ & $\begin{array}{l}99 / V \\
(94 / 9)\end{array}$ & $\begin{array}{l}1 Y Y / 9 \\
(I T Y / Y)\end{array}$ & $\begin{array}{l}\text { YrV/K } \\
(Y Y V / Y)\end{array}$ & $\begin{array}{l}V G / Y \\
(V G / Y)\end{array}$ & $\begin{array}{l}V \pi / 4 \\
(V \circ / 9)\end{array}$ & انحر اف معيار (mm) \\
\hline $\begin{array}{l}0 / 9 \Lambda \\
\left(0 / N{ }^{\mu}\right)\end{array}$ & $\begin{array}{l}0 / 91 \\
(0 / N 0)\end{array}$ & $\begin{array}{l}\circ / N Q \\
(\circ / N Q)\end{array}$ & $\begin{array}{l}\circ / N V \\
(\circ / V Q)\end{array}$ & $\begin{array}{l}0 / 9 \Lambda \\
\left(0 / N^{\mu}\right)\end{array}$ & $\begin{array}{l}\circ / V^{4} \\
(\circ / V \Lambda)\end{array}$ & $\begin{array}{c}0 / 94 \\
(0 / 94)\end{array}$ & $\begin{array}{l}\circ / A Y \\
(0 / V Q)\end{array}$ & ضريب هرست \\
\hline
\end{tabular}


يبشينى روند غيرخطى بارش سالانه در استان كردستان است. از نكات قابل توجـهـ ايـن بـود كـهـ بــا افـزايش كـام زمـانى

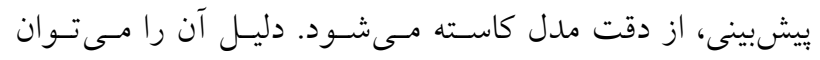

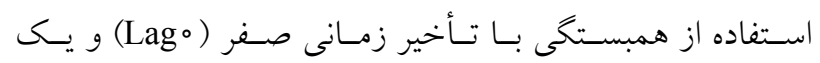
(Lagl)

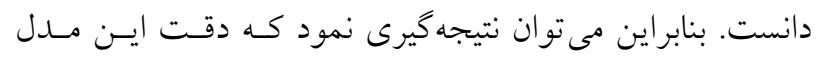

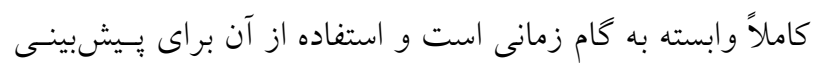

$$
\text { با كام زمانى زياد توصيه نمىشود. }
$$

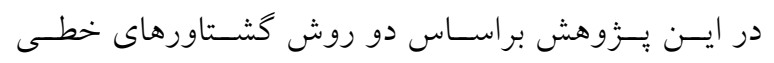

و نمودار احتمال ضـريب همبسـتخى (L-Moments)

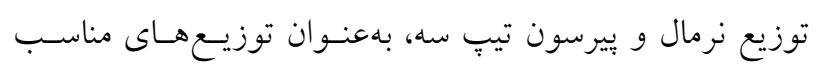

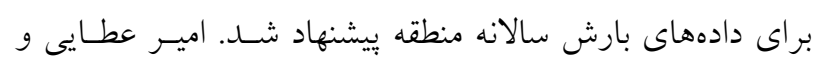

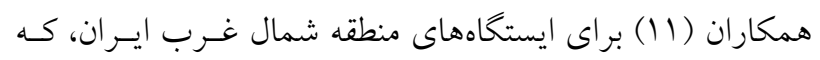

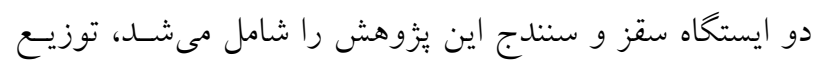

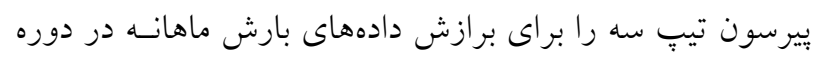

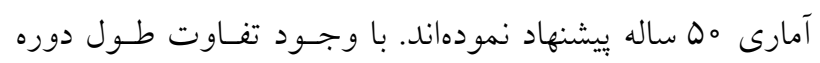

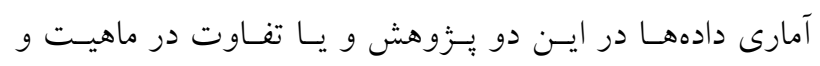
خواص سرىهاى ماهانه و سالانه، نتايج آنها مشابه است.

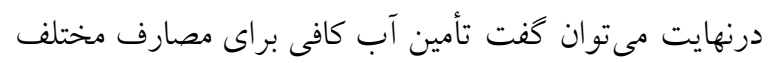
شرب، كشاورزى و صنعت در منطقه كردسـتان و سـاير نقـاط بـهـ

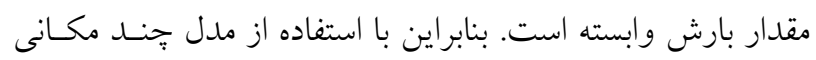

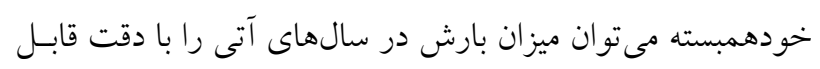

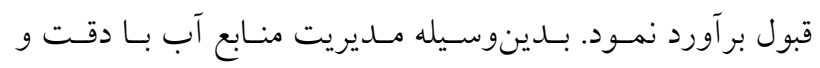

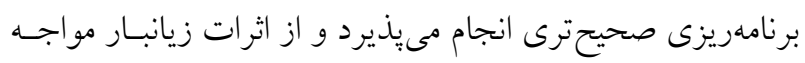

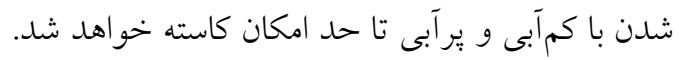

نتيجه گيرى

تغييرات زياد مقدار بارش در نقاط مختلف، كمبـود ايستـاهـــاى

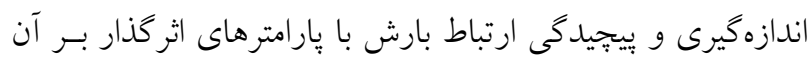

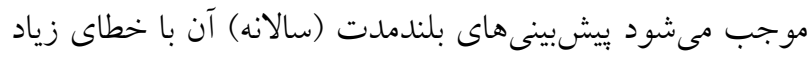

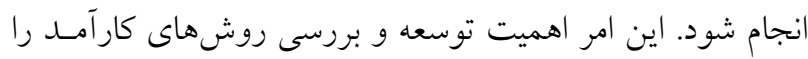

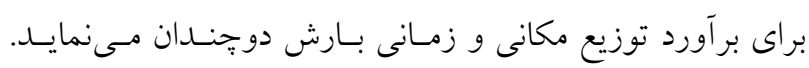

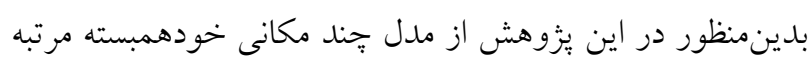

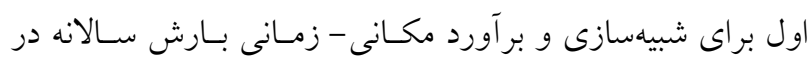

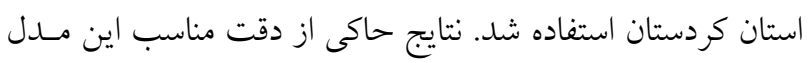

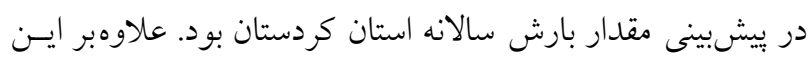

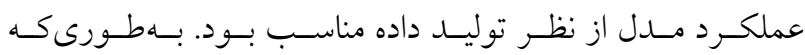

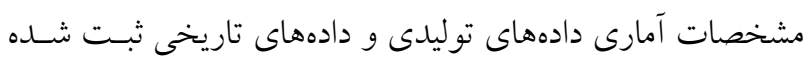

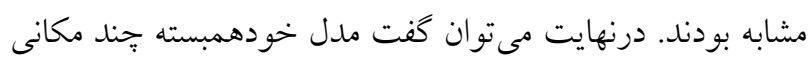

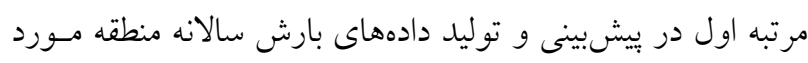

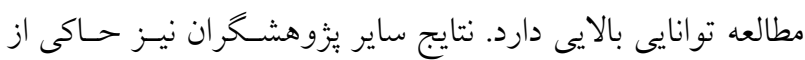

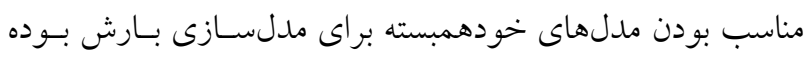

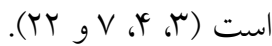

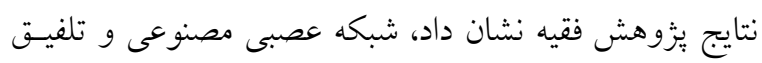

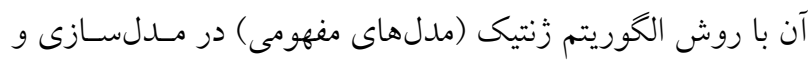
بر آورد مكانى بارش ماهانه منطقه كردستان دقت زيسادى دارد (9).

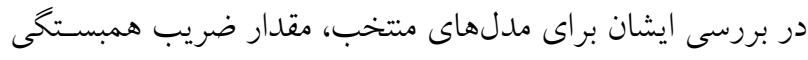

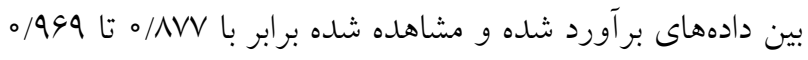

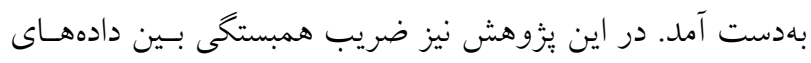

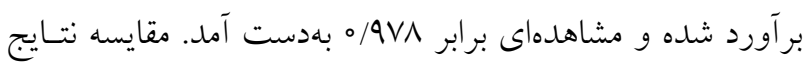

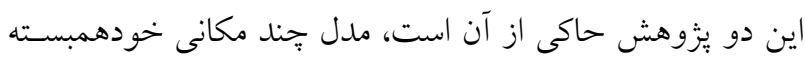

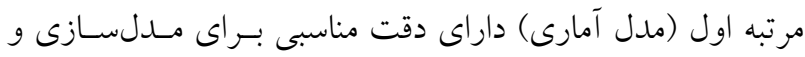

\section{منابع مورد استفاده}

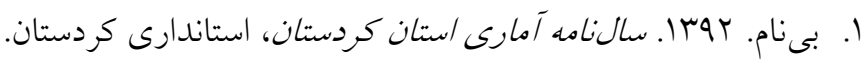

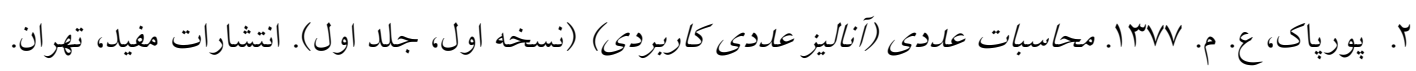

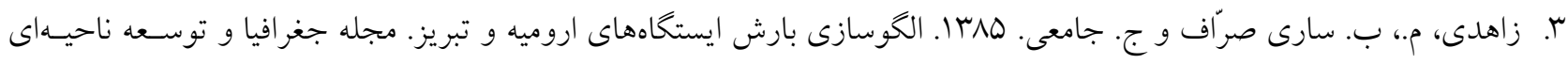




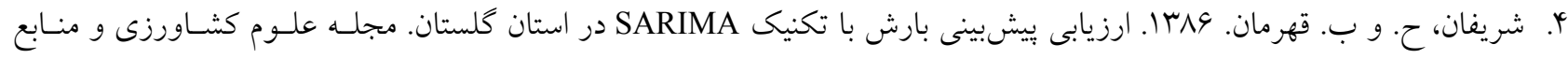

$$
\begin{aligned}
& \text { طبيعى } \\
& \text { ه. عليز اده، ا. اوسا ا. اصول هيدرولوزى كاربردى (نسخه لهr). انتشارات آستان قدس رضوى، مشهد. } \\
& \text { 9. فقيه، ه. 91 ا ا. ارزيابى كاربرد شبكه عصبى مصنوعى و بهينهسازى آن با روش الكوريتم زنتيك در تخمين دادههـاى بـارش ماهانـه }
\end{aligned}
$$

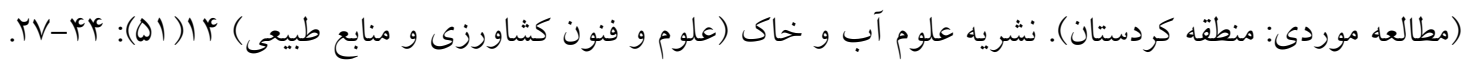

$$
\begin{aligned}
& \text { V. فيروزى، ف.، ح. نگارش و م. خسروى. اqجا. مدلسازى، بيشبينى و بررسى روند بارش در ايستخاههاى منتخـب اسـتان فـارس. }
\end{aligned}
$$

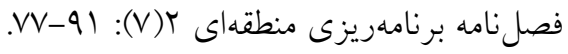

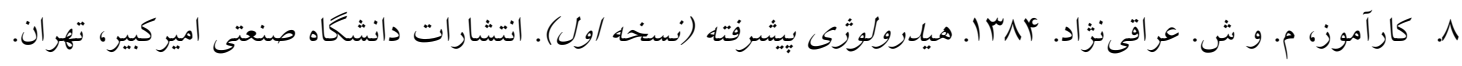

$$
\begin{aligned}
& \text { 9. مروج، م.، ك. خليلى و ج. بهمنش. وجبا. بررسى رابطه بين فرآيندهاى هيدرولوزيك بارش، تبخير و جريان رودخانه با استفاده از } \\
& \text { مدل سرىهاى زمانى خطى (مطالعه موردى: حوضههاى غرب درياجه اروميه). نشريه آب و خاى (علـوم و صسنايع كشـاورزى) } \\
& \text {. } \wedge \Delta-1 \circ 1:(1) Y q
\end{aligned}
$$

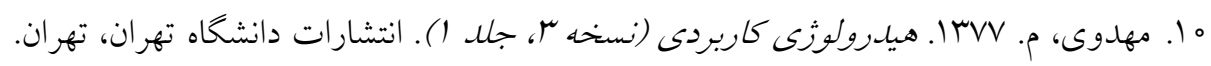

11. Amirataee, B., M. Montaseri and H. Rezaei. 2014. Assessment of Goodness of Fit Methods in Determining the Best Regional Probability Distribution of Rainfall Data. Inter. J. of Eng. 27(10): 1537-1546.

12. Arnell, N. W., M. Beran and J. Hosking. 1986. Unbiased Plotting Positions for the General Extreme Value Distribution. J. of Hydrol. 86(1): 59-69.

13. Box, G. and F. Jenkins. 1976. Times Series Analysis: Forecasting and Control (2 Ed., Vol. 2). Oakland CA: Holden-Day.

14. Chow, V. T. 1954. The log-probability law and its engineering application. Proceedings, ASCE 80: 1-25.

15. Chow, V. T. 1964. Handbook of Applied Hydrology. McGraw-Hill.

16. Filliben, J. J. 1975. The probability plot correlation coefficient test for normality. Technometrics 17(1): 111-117.

17. Hosking, J. R. 1990. L-moments: analysis and estimation of distributions using linear combinations of order statistics. J. of R. Statist. Soc. Series B. 52(1): 105-124.

18. Hosking, J. R. and J. R. Wallis. 2005. Regional Frequency Analysis: An Approach Based on L-moments. Cambridge University Press.

19. Joiner, B. and J. Rosenblatt. 1971. Some Properties of the Range in Samples from Tukey's Symmetric Lambda Distributions. J. of Am. Statist. Ass.66(334): 394-399.

20. Karamouz, M., F. Szidarovszky and B. Zahraie. 1996. Water Resources Systems Analysis. Boca Raton London New York Washington, D. C.

21. Khalili, M., F. Brissette and R. Leconte. 2011. Effectiveness of multi-site weather generator for hydrological modeling. J. of Am. Water Resour. Assoc. 47(2): 303-314.

22. Komornık, J., M. Komornıkova, R. Mesiar and D. Szokeova. 2006. Comparison of Forecasting Performance of Nonlinear Models of Hydrological Time Series. Phys. Chem. Earth 31: 1127-1145.

23. Mamdouh, S., H. J. Van Oorschot and S. J. De Lange. 1993. Statistical Analysis in Water Resources Engineering. Rotterdam: A.A. Balkema.

24. Manzer, D. and M. Barnett. 1966. Analysis by High Speed Digital Computer in Design of Water Resources Systems. Harvard University Press.

25. Matalas, N. C. 1967. Mathematical Assessment of Synthetic Hydrology. Water Resour. Res. 3(4): $937-945$.

26. Patra, K. C. 2001. Hydrology and Water Resources Engineering. New Delhi: Narosa Publishing House.

27. Saada, N. 2014. Time Series Modeling of Monthly Rainfall in Arid Areas: Case Study For Saudi Arabia. Am. J. of Environ. Sci. 10(3): 277-282.

28. Siegel, S. and J. Castellan. 1998. Nonparametric Statistics for the Behavioral Sciences (2 Ed.)., New York: Mc Graw-Hill.

29. Srikanthan, R. and T. A. McMahon. 1985. Stochastic Generation of Rainfall and Evaporation Data. AWRC (84): 301.

30. Thomas, H. and M. Fiering. 1962. Mathematical synthesis of streamflow sequences for the analysis of river basins by simulation. In: A. Maass, S. Marglin and G. Fair (Ed.), Design of Water Resource Systems. Harward University Press, Cambridge. 
31. Thyer, M. and G. Kuczera. 1999. Modelling long-term persistence in rainfall time series, sydney rainfall case study. Hydrology and Water Resources Symposium. Australia: Institution of Engineers. PP: 550-555

32. Vogel, R. M. and C. N. Kroll. 1989. Low-flow frequency analysis using probability-plot correlation coefficients. J. of Water Resour. Plan. and Manage. 115(3): 338-357.

33. Vogel, R. and I. Wilson. 1996. Probability distribution of annual maximum, mean, and minimum streamflows in the united states. J. of Hydrol. Eng. 1(2): 69-76.

34. Wang, H., C. Wang, X. Lin and J. Kang. 2014. An improved ARIMA model for precipitation simulations. Nonlinear Process. Geophys. 21: 1159-1168.

35. Wilson, E. and M. Hilferty. 1931. The distribution of chi-square. Proc. Natl. Acad. Sci. U.S.A. 17(12): $684-688$.

36. Young, G. and W. Pisano. 1968. Operational hydrology using residuals. J. of Hydr. Div. ASCE. 94: 909-923.

37. Yue, S., P. Pilon and G. Cavadias. 2002. Power of mann-kendall and spearman's Rho tests for detecting monotonic trends in hydrological series. J. of Hydrol. 259: 254-271. 


\title{
Simulation of Spatiotemporal Annual Precipitation Using Stochastic Models
}

\author{
H. Faghih ${ }^{1 *}$, J. Behmanesh ${ }^{2}$ and K. Khalili ${ }^{2}$
}

(Received: Jan. 9-2017; Accepted: May 15-2017)

\begin{abstract}
Precipitation is one of the most important components of water balance in any region and the development of efficient models for estimating its spatiotemporal distribution is of considerable importance. The goal of the present research was to investigate the efficiency of the first order multiple-site auto regressive model in the estimation of spatiotemporal precipitation in Kurdistan, Iran. For this purpose, synoptic stations which had long time data were selected. To determine the model parameters, data covering 21 years $r$ (1992-2012) were employed. These parameters were obtained by computing the lag zero and lag one correlation between the annual precipitation time series of stations. In this method, the region precipitation in a year $(\mathrm{t})$ was estimated based on its precipitation in the previous year ( $\mathrm{t}-1)$. To evaluate the model, annual precipitation in the studied area was estimated using the developed model for the years 2013 and 2014; then, the obtained data were compared with the observed data. The results showed that the used model had a suitable accuracy in estimating the annual precipitation in the studied area. The percentages of the model in estimating the region's annual precipitation for the years 2013 and 2014 was obtained to be $7.9 \%$ and $17.3 \%$, respectively. Also, the correlation coefficient between the estimated and observed data was significant at the significance level of one percent $(\mathrm{R}=0.978)$. Furthermore, the model performance was suitable in terms of data generation; so the statistical properties of the generated and historical data were similar and their difference was not significant. Therefore, due to the suitable efficiency of the model in estimating and generating the annual precipitation, its application could be recommended to help the better management of water resources in the studied region.
\end{abstract}

Keywords: Auto regressive, Forecast, Kurdistan, Simulation, Stochastic model, Time series.

1. Soil and Water Res. Dept., Kurdistan Agric. and Natural Resour. Res. and Educat. Center, AREEO, Sanandaj, Iran.

2. Dept. of Water Eng., Faculty of Agric., Urmia Univ., Urmia, Iran.

*: Corresponding Author, Gmail: hfkuir@gmail.com 